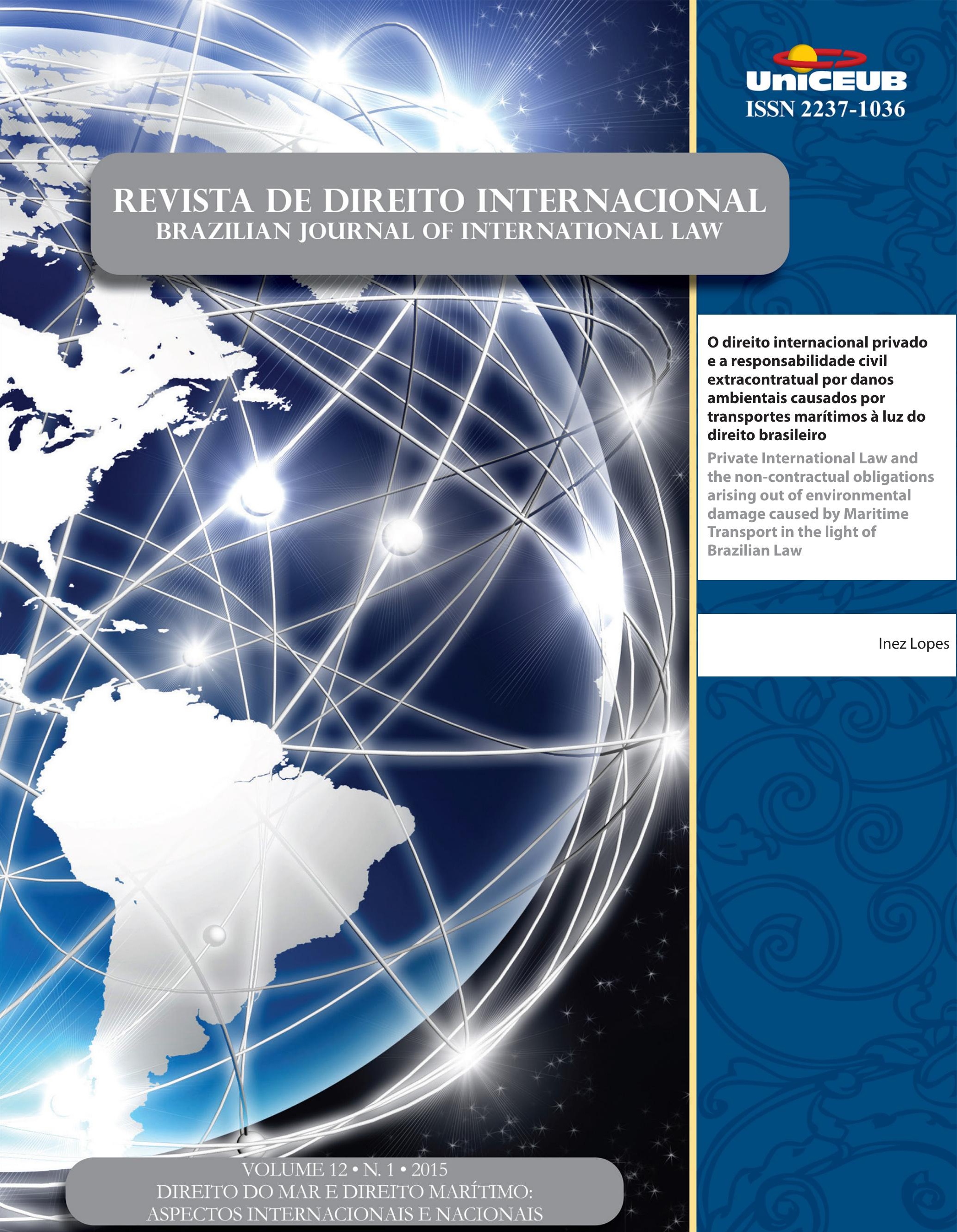




\section{Sumário}

\section{Crônicas}

CRôNICAS DA ATUALIDADE do DiREITO INTERNACIONAL ........................................................ 2

Nitish Monebhurrun (org.)

Towards a european regulation of the importation of conflict minerals?..... 2

Nitish Monebhurrun

Keeping up with the terrorists: the EU's proposed Passenger Name Records (PNR) Directive \& european security

Eshan Dauhoo

A histórica reaproximação de Cuba e EUA

Erika Braga

A contextualização da atual reivindicação da Grécia para receber indenizações por atos da Alemanha durante a Segunda Guerra Mundial . .10

Natália da Silva Gonçalves

José Eduardo Paiva Miranda de Siqueira

Crônicas da jurisprudência do Direito Internacional (CIJ/ITLOS): Decisões da Corte Internacional de Justiça e do Tribunal Internacional Sobre o Direito do Mar .14

Nitish Monebhurrun (Org.)

Corte Internacional de Justiça

Estudo da decisão da Corte Internacional de Justiça no caso Croácia v. Servia (03/02/2015) .14

Liziane Paixão Silva Oliveira e Maria Edelvacy Marinho

Questões relacionadas com a apreensão e detenção de certos documentos e dados: (Timor Leste c. Austrália) - O reconhecimento do retorno de uma relação amigável entre Timor-Leste e Austrália e a nova decisão da CIJ, 6 de maio de 2015 . 20

Gleisse Ribeiro Alves

Tribunal Internacional sobre Direito do Mar

Caso da delimitação da fronteira marítima entre o Gana e a Costa do Marfim no Oceano Atlântico: medidas cautelares $(25 / 04 / 2015)$

Nitish Monebhurrun

Comentário à Opinião Consultiva 21 do Tribunal Internacional para o Direito Do Mar [02/04/2015] (Responsabilidade do Estado de Bandeira pela pesca ilícita, não declarada ou não regulamentada) ...............25

Carina Costa de Oliveira 
CRÔNICAS DO DIREITO INTERNACIONAL DOS INVESTIMENTOS

Nitish Monebhurrun (Org.)

A inclusão da responsabilidade social das empresas nos novos Acordos de Cooperação e de Facilitação dos Investimentos do Brasil: uma revolução 33

Nitish Monebhurrun

\section{O Direito do Mar Perante as JuRisdições INTERnacionais}

CoAstal States' Rights IN THE MARITIME AREAS UNDER UNCLOS .40 Tullio Treves

TACKling illegal, unregulated And unReported Fishing: THE ITLOS Advisory OpINION on Flag State Responsibility for IUU fishing AND THE PRINCiple of DUE DiligenCE ...50 Victor Alencar Mayer Feitosa Ventura

REFLEXões PROVENIENTES do DisSENSO: UMA ANÁLISE CRÍtica A RESPEITO do CASO Austrália versus Japão Perante a Corte InTERnacional de JustiçA .......................................68 Luciana Ferna ndes Coelho

Os TRATADOS INTERNACIONAIS DE DIREITO DO MAR E SEUS EFEITOS SOBRE TERCEIROS ESTADOS ..... 86 Tiago V. Zanella

\section{InStRumentos JURÍdicos PARA A GeStÃo do MAR}

OS LIMITES DOS TERMOS BEM PÚBLICO MUNDIAL, PATRIMÔNIO COMUM DA HUMANIDADE E BENS COMUNS PARA DELIMITAR AS OBRIGAÇÕES DE PRESERVAÇÃO DOS RECURSOS MARINHOS 109 Carina Costa de Oliveira e Sandrine Maljean-Dubois

Os limites do PLANEJAMENTO DA OCUPAÇÃo SUSTENTÁVEL DA ZONA COSTEIRA BRASILEIRA ... 126 Carina Costa de Oliveira e Luciana Coelho

CORRENDO PARA O MAR NO ANTROPOCENO: A COMPLEXIDADE DA GOVERNANÇA DOS OCEANOS E A ESTRATÉGIA BRASILEIRA DE GESTÃO DOS RECURSOS MARINHOS 
A comissão de limites da Plataforma continental (CLPC) E Os DESAFios Na delineaÇÃo DAS PLATAFORMAS CONTINENTAIS ESTENDIDAS................................................... 170

Alexandre Pereira da Silva

\section{A PROTEÇÃo DO MEIO AMBIENTE MARINHO}

O gRANDE JOGo do ÁrTiCo: REFLEXões COM BASE NA PERSPECTIVA DE EXPLORAÇão ECONÔMICA

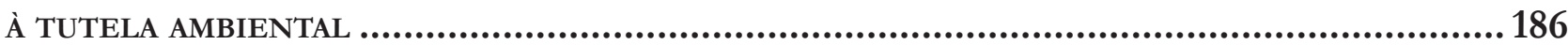

Fernando Rei e Valeria Cristina Farias

Instrumentos Públicos e Privados para a reparação do dano ambiental causado por DERRAMAMENTO DE ÓLEO NO MAR SEM ORIGEM DEFINIDA: AS MANCHAS ÓRFÃS

Renata Brockelt Giacomitti e Katya R. Isaguirre-Torres

O DIREITO INTERNACIONAL PRIVADO E A RESPONSABILIDADE CIVIL EXTRACONTRATUAL POR DANOS AMBIENTAIS CAUSADOS POR TRANSPORTES MARÍTIMOS À LUZ DO DIREITO BRASILEIRO ....... 217 Inez Lopes

A NECESSIDADE DE REPENSAR OS MECANISMOS DE RESPONSABILIDADE AMBIENTAL EM CASO DE riscos de VAZamento de PETRóleo Na Zona Econômica Exclusiva do BrasiL

Marcelo D. Varella

\section{Problemáticas do Direito Marítimo}

A FisCALIZAÇão SANitÁRIA DAS EMBARCAÇÕES EM ÁGUAS JURISDICIONAIS BRASILEIRAS: NOTAS aCERCA da (IN)efetividade da Súmula 50 da AGU

Joedson de Souza Delgado e Ana Paula Henriques da Silva

A IMO E A REPRESSÃo AO ROUBO ARMADO CONTRA NAVIOS: DA RETÓRICA INTERNACIONAL À COOPERAÇÃO REGIONAL

André Panno Beirão e Charles Pacheco Piñon

\section{O Direito do Mar diante da Pirataria}

O DIREITO INTERNACIONAL EM FACE DA PIRATARIA EM ALTO-MAR: UMA PERSPECTIVA CRÍTICA.289 Maiquel Ângelo Dezordi Wermuth e Rafaela Correa 
Pirataria marítima: A EXPERIÊnCIA Somália

Eduardo Augusto S. da C. Schneider

\section{Temas Gerais}

DRAWING THE LINE: ADDRESSING ALLEGATIONS OF UNCLEAN HANDS IN INVESTMENT ARBITRATION*

Mariano de Alba

Para Que Serve a história do Direito internacional?

George Rodrigo Bandeira Galindo

As interferências entre a Política Externa e de Segurança Comum Europeia (Pesc) e O DiREITO DAS NaÇões UNIDAS

Leonardo de Camargo Subtil

Introdução Às regras de aplicaÇão da Convenção da ONU Sobre Contratos de ComPRA E VENDA INTERNACIONAL DE MERCADORIAS E O DIREITO INTERNACIONAL PRIVADO BRASI-

LEIRO 380

Paul Hugo Weberbauer e Eugênia Cristina Nilsen Ribeiro Barza

A REgulaÇÃo das EMPRESAS TRANSNACIONAIS ENTRE AS ORDENS JURÍDICAS ESTATAIS E NÃO ESTATAIS.

Mateus de Oliveira Fornasier e Luciano Vaz Ferreira

OUtLAWING HATE SPEECH IN DEMOCRATIC STATES: THE CASE AGAINST THE INHERENT LimitAtions doctrine concerning Article 10 (1) of the European Convention on Human

Rights 416

Stefan Kirchner 


\title{
O direito internacional privado e a responsabilidade civil extracontratual por danos ambientais causados por transportes marítimos à luz do direito brasileiro*
}

\author{
Private International Law and the non- \\ contractual obligations arising out of \\ environmental damage caused by Maritime \\ Transport in the light of Brazilian Law
}

Inez Lopes**

\section{Resumo}

Mais de 90\% do comércio internacional é realizado por meio de transportes marítimos, sendo a indústria da navegação uma das maiores do mundo em geração de riquezas e de empregos. Paralelamente, é uma das atividades potencialmente poluidora ao meio ambiente marinho, uma vez que mais de $50 \%$ da carga comercializada é considerada perigosa ou nociva. Atualmente, os transportes marítimos são responsáveis por $12 \%$ da poluição marinha, que podem ocorrer em águas territoriais ou águas internacionais. Por sua vez, a lei da bandeira ou do pavilhão constitui um elemento de conexão importante para se determinar a responsabilidade do agente causador do dano. Contudo, há a possibilidade de os navios arvorarem outra bandeira que não a de sua nacionalidade, além das bandeiras de conveniência. Desse modo, o presente artigo objetiva estudar a responsabilidade civil extracontratual por danos ambientais marinhos causados por transportes marítimos nas situações privadas internacionais à luz do direito brasileiro, considerando-se os danos em águas territoriais e em alto-mar, limitando-se à análise de casos de poluição por óleo e outras substâncias nocivas ou perigosas. A partir da análise qualitativa, o texto discute questões referentes à nacionalidade do navio, e os problemas referentes à responsabilização dos navios que utilizam bandeiras de conveniência. Analisa as regras de direito internacional privado quanto à lei aplicável na responsabilidade extracontratual e a adoção da lex damni aos casos de danos ambientais. Com relação à competência internacional, aplica-se a regra do forum damni, a fim de oferecer maior segurança e previsibilidade aos litígios transfronteiriços. Todavia, ainda há necessidade de se aperfeiçoar a cooperação jurídica transfronteiriça em matéria ambiental.

Palavras-chave: Direito internacional privado. Responsabilidade civil extracontratual. Danos ambientais. Poluição marinha. Transportes marítimos.

** Professora-adjunta de Direito Internacional Privado da Universidade de Brasília (UnB). Doutora e Mestre em Direito Internacional pela Universidade de São Paulo (USP). Mestre em Globalização e Políticas Trabalhistas pela Universität Kassel/FHW Berlin. Ex-Coordenadora-Geral de Cooperação Jurídica Internacional em Matéria Civil do Ministério da Justiça (DRCI/SNJ/MJ). Coordenadora do Grupo de Estudos em Direito Internacional Privado, do Comércio Internacional e Direitos Humanos (CNPq).E-mail: inezlopes@unb.br 


\section{Abstract}

Over $90 \%$ of international trade is carried out through maritime transport and shipping is one of the world's great industries in generating wealth and jobs. At the same time, it is one of potentially polluting activities to the marine environment, since more than $50 \%$ packaged goods and bulk cargoes transported by sea can be dangerous or harmful. Currently, maritime transport accounts for $12 \%$ of marine pollution, which may occur in territorial waters or international waters. In turn, the law of the flag is an important connecting factor to determine the agent's liability for causing the damage. However, it is possible for ships to fly another flag than of its nationality in addition to flags of convenience. Thus, this article aims to study the non-contractual liability for environmental damage caused by marine shipping in private international relations in the light of Brazilian law, considering the damage in territorial waters and on the high seas, limited to the analysis of cases of pollution by oil and other harmful or dangerous substances. From the qualitative analysis, the paper discusses issues related to ship's nationality, and problems relating to accountability ships using flags of convenience. It also analyzes the rules of private international law and the applicable law in non-contractual liability and the adoption of lex damni to cases of environmental damage. In regard to international jurisdiction, it is applied the rule of forum damni in order to provide greater certainty and predictability on cross-border disputes. However, there is still need to improve cross-border legal cooperation on environmental issues.

Keywords: Private international law. Non-contractual liability. Environmental damages. Marine pollution. Maritime transports.

\section{INTRODUÇÃo}

A indústria da navegação é responsável pelo grande fluxo de mercadorias no comércio internacional. Os principais motivos são o custo operacional em comparação aos demais meios de transporte e a capacidade de armazenamento de mercadorias, desde matérias-primas e produtos tecnológicos de alto valor agregado. Apesar disso, a atividade marítima é considerada de alto risco e, de acordo com os critérios da Organização Marítima
Internacional $(\mathrm{OMI})^{1}$, mais de $50 \%$ dos produtos embalados e de cargas a granel podem ser considerados perigosos ou nocivos ao meio ambiente, dependendo do tipo de carga que é transportada, como por exemplo, os produtos a granel, contendo líquidos ou sólidos inflamáveis, materiais radioativos, petróleo e seus derivados e lixo.

Entende-se por transportes marítimos os transportes aquaviários destinados ao deslocamento de pessoas e de mercadorias em águas territoriais (águas interiores e marítimas) e em águas internacionais (alto-mar). O direito marítimo regula as atividades comerciais realizadas por navegação, bem como as atividades de exploração dos recursos naturais marinhos vivos e não vivos de águas interiores.

O direito ambiental, por sua vez, regula as atividades de navegação, a fim de evitar danos ao patrimônio marinho. A potencialidade de dano é elevada e as normas internas e internacionais visam estabelecer uma harmonização nos mecanismos preventivos de poluição, assim como de responsabilidade do poluidor e de sua obrigação de reparar ou prejuízo.

Desse modo, a efetividade na proteção dos recursos marinhos, vivos e não vivos, depende da participação de todos os stakeholders da sociedade internacional, como as empresas (instituições econômicas) e a sociedade civil (instituições sociais), em sentido amplo, além dos Estados e das organizações internacionais (instituições políticas). Os danos causados ao meio ambiente marinho é um tema global e depende da cooperação internacional entre os Estados para estabelecer regras comuns para uma gestão pública internacional sustentável, tanto no uso quanto na exploração de recurso vivos e não vivos que constituem se bem público global.

A responsabilidade civil por danos ao meio ambiente marinho pode ser internacional, responsabilizando os Estados por danos causados por embarcações que estejam em seu território e causem prejuízos às populações de Estados vizinhos ou em águas internacionais quando o dano for provocado por embarcação que arvore sua bandeira. Nas relações privadas internacionais, as em-

1 ORGANIZAÇÃO MARÍTIMA INTERNACIONAL. IMO and dangerous goods at sea: The transport by sea of dangerous and harmful goods, including marine pollutants and wastes Focus on IMO. May 1996. Disponível em: < http://www.imo.org/blast/blastDataHelper.asp?data_id $=7999 \&$ filename $=$ IMDGdangerousgoodsf ocus1997.pdf>. Acesso em: 12 jul. 2014. 
presas de navegação, nacionais e estrangeiras, podem ser responsabilizadas pelos prejuízos nas operações comerciais internacionais, seja de natureza contratual, seja extracontratual, como é o caso da poluição marinha, causada por vazamento de substâncias altamente perigosas e nocivas, como hidrocarbonetos.

Este trabalho objetiva em especial estudar o direito internacional privado e a responsabilidade extracontratual por danos ambientais marinhos decorrentes das atividades de navegação, em especial as regras de conexão sobre conflitos de leis e de jurisdição, bem como a questão da nacionalidade dos navios e os problemas referentes à responsabilização dos navios que utilizam bandeiras de conveniência. Visando atingir seu propósito, este artigo está dividido em três partes. A primeira parte estuda o desenvolvimento do comércio marítimo internacional, o fenômeno da globalização e o marco regulatório na relação entre transporte marítimo e meio ambiente. A segunda parte estuda o direito internacional privado e a responsabilidade civil extracontratual nas atividades marítimas. A partir da análise qualitativa, analisa as regras de direito internacional privado quanto à lei aplicável na responsabilidade extracontratual e a adoção da lex damni aos casos de danos ambientais. Com relação à competência internacional, aplica-se a regra do forum damni, a fim de oferecer maior segurança e previsibilidade aos litígios transfronteiriços. Por meio do método analítico, a terceira parte estuda a jurisprudência dos tribunais brasileiros com relação às regras de competência internacional para poluição marinha de hidrocarbonetos e seus derivados, causado por navios, bem como os conflitos de competência judiciária e administrativa.

\section{GLobalizAÇÃo, tRANSPORTE MARÍtIMO E MEIO AMBIENTE}

O comércio marítimo internacional é tão antigo quanto a história da civilização humana. Contudo, até o início do século XX, as legislações se limitavam a estabelecer responsabilidades civis para reparação patrimonial, como no caso de colisão ou abalroamento e, também, de ordem administrativa para responsabilizar a tripulação das embarcações.

Embora a história tenha registrado a existência de relações comerciais internacionais nas antigas civiliza- ções, o marco inicial na história do desenvolvimento do direito do comércio internacional surge na Idade Média. De acordo como Schmitthoff ${ }^{2}$, a característica internacional do antigo direito do comerciante na Idade Média decorria de quatro fatores. O primeiro fator tinha efeito unificador da lei de mercado, e era quase tão universal quanto a lei da igreja. O segundo tinha relação com a universalidade da alfândega marítima (portuária). Esse fator apareceu com os fenícios e os gregos, cujas regras estavam reunidas nas leis de Rodes, entre 600 e 800 a.C. Nesse período surgiu o repertório (repositórios) de decisões e de costumes, tais como o Rôles d'Oleron, na França, Consuldado del Mar, de Barcelona, e tantos outros, e o último se tornou mais tarde o Código Marítimo do Mediterrâneo. O terceiro fator referia-se aos tribunais especiais que lidavam com as disputas comerciais. Interessante notar que esses tribunais eram constituídos metade por jurados nativos e metade por comerciantes estrangeiros, conhecidos como "half-tongue juries". O último fator estava relacionado à atividade do tabelião, que, na Idade Média, era um praticante universal e versátil, e lidava basicamente com o trabalho jurídico comercial.

Os comerciantes europeus criaram um conjunto de normas costumeiras internacionais que regulavam as práticas e costumes da comunidade cosmopolita ${ }^{3}$. Esse período ficou conhecido com a antiga lex mercatoria. Essas normas foram se espalhando pela Europa, devido ao fato de os comerciantes aplicarem essas regras nas suas transações comerciais internacionais, independentemente do lugar da negociação, fossem em mercados nacionais, fossem em centros estrangeiros, e também da lei local.

Outra importante fase do desenvolvimento do direito do comércio internacional ocorreu entre os séculos XVII e XIX, marcado pela incorporação das leis dos comerciantes - conjunto de leis internacionais costumeiras - ao ordenamento jurídico interno em diversos países. Em outras palavras, a inserção da antiga lex mercatoria no sistema nacional dos Estados.

Nesse período, as atividades desenvolvidas pela comunidade do comércio internacional deram origem a

2 CHENG, Chia-Jui (Ed.). Clive M Schmitthoff's Select Essays on International Trade Law. Dordrecht: Martinus Nijhoff Publishers; Boston, London: Graham \& Trotman, 1982. p. 207

3 CHENG, Chia-Jui (Ed.). Clive M Schmitthoff's Select Essays on International Trade Law. Dordrecht: Martinus Nijhoff Publishers; Boston, London: Graham \& Trotman, 1982. p. 206. 
novos costumes internacionais. Foram criadas novas formas de contratos de venda internacional, como os contratos com cláusulas Free on Board (FOB). ${ }^{4}$ e Cost, Insurance and Freight $(\mathrm{CIF})^{5}$. Mais tarde, surgiu o crédito bancário comercial, usado como meio de pagamento nos negócios de exportação.

A globalização não é um processo novo. Analisando-se a concepção de globalização econômica, o final do século XIX e o princípio do XX (1870-1914) foram marcados por um fenômeno semelhante ao da globalização do final do século XX. Nesse contexto, Ianni afirma que a globalização evoluiu do mercantilismo, passando pelo colonialismo, imperialismo, multinacionalismo e transnacionalismo, transformando-se em um modo de produção global ${ }^{6}$.

Nesse sentido, o fenômeno da globalização está profundamente vinculado à ordem econômica internacional marcada pela aceleração do mercado, com a expansão do comércio internacional e de investimentos financeiros internacionais. Por sua vez, a distribuição da produção mundial é realizada por transporte marítimo em mais de $90 \%$ do volume comercializado no mundo, isso significa que "o transporte marítimo é um dos fatores mais importantes da globalização e ao mesmo tempo a globalização é um dos fatores mais importantes de demanda no transporte marítimo". ${ }^{7}$ Ademais, o eterno triângulo formado por produtores, fabricantes e mercados está unido por meio de transportes. ${ }^{8}$

Com o objetivo de estabelecer um marco regulatório sobre direito marítimo, a Organização Marítima Internacional (IMO) foi criada em 1948, inicialmente como Organização Intergovernamental Marítima Consultiva, uma agência especializada do sistema das Nações Uni-

4 O primeiro caso de contrato f.o.b. foi entre Wackerbarth v. Masom em 1812.

5 O primeiro caso de contrato c.i.f. foi entre Tregelles v. Sewell em 1862.

6 IANNI, Otavio. Teoria da globalização. Rio de Janeiro: Civilização Brasileira, 1997.

7 POCUCA, Milojka; ZANNE Marina. Globalization, International Trade and Maritime Transport. Disponível em: <http://www. google.com.br $/$ url? sa $=$ t\&rct $=j \& q=\&$ esrc $=s \&$ source $=$ web\&cd $=1 \&$ ved $=0 \mathrm{CCkQFjAA \& url}=$ http $\% 3 \mathrm{~A} \% 2 \mathrm{~F} \% 2 \mathrm{Fwww}$.fpp.uni-lj. si\%2Fmma_bin.php\%3Fid\%3D2010101801382606\&ei=cd5CVe3 EOuTbsASIIYC4Cw\&usg=AFQjCNE5Mo84x6uOhgE_TQRHgmQBkgnxA\&sig2=6EtfrO-byPWfFjysUpHpqA\&bvm=bv.921894 99,d.cWc >. Acesso em: 9 mar. 2015.

8 ORGANIZAÇÃO MARÍTIMA INTERNACIONAL. International Shipping Facts and Figures. Maritime Knowlegde Centre, 2012. p. 6. das, a fim de promover uma navegação marítima mais segura e, também, para maior efetividade na prevenção e no controle de poluição marinha. Seus trabalhos tiveram início em 1959, e é responsável pela construção de um arcabouço jurídico internacional, tais como Convenção Internacional para Salvaguarda da Vida Humana no Mar (SOLAS 74) e do Protocolo relativo 1988 (SOLAS 88), a Convenção Internacional para Prevenção da Poluição por Navios e seu Protocolo de 1978 (MARPOL 73/78) entre outros. Atualmente a instituição conta com 170 membros $^{9}$ e seus trabalhos. Estudos da OMI revelam que o transporte marítimo é o meio mais eficiente e eficaz em termos de custos e de confiança no transporte de mercadorias em nível global, facilitando o comércio e ajudando a criar prosperidade entre povos e nações.

Por seu turno, a Conferência das Nações Unidas sobre Comércio e Desenvolvimento (UNCTAD), agência especializada do sistema das Nações Unidas que objetiva promover o comércio e desenvolvimento entre as nações, exerce importante trabalho sobre comércio marítimo, com a compilação de informações estatísticas sobre o transporte marítimo no mundo. A UNCTAD publica anualmente uma série estudos intitulada "O Transporte Marítimo" (Review of Maritime Law) desde 1968, com o propósito promover a transparência dos mercados de transportes marítimos assim como apresentar uma análise de sua evolução.

As atividades de navegação trazem em si o problema da responsabilidade civil, contratual e extracontratual, assim como toda manifestação da atividade humana traz em si o problema da responsabilidade ${ }^{10}$, uma vez que são consideradas atividades de alto risco em potencial, pois se destinam ao transporte de pessoas e coisas. Ao transporte marítimo é atribuída, ainda, a função de entregar ou enviar notícias, podendo ser reconhecida a reponsabilidade por danos em caso de demora culposa ou de informação errônea transmitida. O presente trabalho se limita a estudar apenas os casos de responsabilidade civil por danos ao meio ambiente marinho, de recursos vivos e não vivos.

A relação entre proteção internacional do meio ambiente e o direito marítimo estabelece obrigações

9 Dados obtidos <http://www.imo.org >. Acesso em: 17 abr. 2015.

10 Ver DIAS, José de Aguiar. Da responsabilidade civil. 10. ed. Rio de Janeiro: Forense, 1997. 
a todos os stakeholders. De um lado temos a obrigação dos Estados de controlar as atividades que estão sob sua jurisdição de tal modo que não causarem danos ao meio ambiente de outros Estados ou além dos limites da jurisdição nacional, conforme dispõem os princípios $2^{\circ}$ da Declaração do Rio sobre Meio Ambiente e Desenvolvimento, de $1992^{11}$ e 21 da Declaração de Estocolmo sobre Meio Ambiente Humano, de 1972, ${ }^{12}$ a chamada poluição transfronteiriça, responsabilizando os Estados em caso de danos. De outro, as pessoas privadas têm a obrigação de usar os espaços territoriais que estão sob a jurisdição do Estado e os espaços comuns que estão sob a proteção do direito internacional de modo a não causar danos.

A Convenção das Nações Unidas sobre Direito do Mar (CNUDM) define poluição introdução pelo homem, direta ou indiretamente, de substâncias ou de energia no meio marinho, incluindo os estuários, sempre que esta provoque ou possa vir a provocar efeitos nocivos, tais como danos aos recursos vivos e à vida marinha, riscos à saúde do homem, entrave às atividades marítimas, incluindo a pesca e as outras utilizações legítimas do mar, alteração da qualidade da água do mar, no que se refere à sua utilização, e deterioração dos locais de recreio ${ }^{13}$; e aos Estados o dever de não transferir danos ou riscos ou de não transformar um tipo de poluição em outro nos termos do artigo 195.

Além disso, a convenção consagra o princípio da cooperação internacional em níveis global, regional e local na formulação e elaboração de regras e normas de uso sustentável domar, bem como práticas e procedimentos recomendados de caráter internacional que sejam compatíveis com o tratado para a proteção e preservação do meio marinho, tendo em conta as características próprias de cada região, conforme o artigo 197.

11 Princípio 2 - "Os Estados, de acordo com a Carta das Nações Unidas e com os princípios do direito internacional, têm o direito soberano de explorar seus próprios recursos segundo suas próprias políticas de meio ambiente e de desenvolvimento, e a responsabilidade de assegurar que atividades sob sua jurisdição ou seu controle não causem danos ao meio ambiente de outros Estados ou de áreas além dos limites da jurisdição nacional".

12 Princípio 21 - "De acordo com a Carta das Nações Unidas e com os princípios do direito internacional, os Estados têm o direito soberano de explorar seus próprios recursos, de acordo com a sua política ambiental, desde que as atividades levadas a efeito, dentro da jurisdição ou sob seu controle, não prejudiquem o meio ambiente de outros Estados ou de zonas situadas fora de toda a jurisdição nacional".

13 CNUDM, artigo $1^{\circ}, 1$ (4).
Importante salientar que a poluição marinha não é apenas causada por transportes marítimos, objeto do presente trabalho, mas também por outras atividades que são realizadas em portos, na exploração econômica dos espaços marítimos, incluindo os fundos do mar entre outros ${ }^{14}$. O Grupo Conjunto de Expertos OMI/ FAO/UNESCO-COI/OMM/OMS/OIEA/ONU/ PNUMA sobre Aspectos Científicos de Proteção do Meio Ambiente Marinho (Joint Group of Experts on the Scientific Aspects of Marine Environmental Protection - GESAMP) realizou estudos sobre a poluição marinha e levantou as principais causas. ${ }^{15}$

Esses estudos revelaram que a poluição causada por transportes marítimos representa um total de 12\% do total. A principal causa de poluição marinha é de origem terrestre incluindo rios, estuários, dutos e instalações de descarga, por lançamento de esgoto, lixos urbanos e industriais ao meio ambiente marinho. A responsabilidade civil é um importante instrumento jurídico para garantir a punição daquele que causou poluição, além dos casos mais graves que enseja a responsabilidade criminal, seja pessoa natural ou jurídica causadora do dano.

\section{O DiREITO INTERNACIONAL PRIVADO E A RESPONSABILIDADE CIVIL EXTRACONTRATUAL NAS ATIVIDADES MARÍTIMAS}

A relação entre o direito internacional privado e o direito marítimo é consequência do fenômeno da globalização econômica que intensificou o comércio entre as nações, diluindo as fronteiras dos Estados. A indústria da navegação é uma das maiores do mundo, uma vez que o transporte marítimo constitui o principal meio de distribuir a produção mundial, em virtude do custo e da possiblidade de carregar diversos produtos. Nesse cenário, "as fronteiras nacionais oferecem poucos impedimentos às empresas multinacionais" ${ }^{16}$. Isso potencializa

14 SCOVAZZI., Tullio. Chapter 13 Maritime Accidents with Particular Emphasis on Liability and Compensation for Damage from the Exploitation of Mineral Resources of the Seabed, p. 287-320. In: GUTTRY, Andrea; GESTRI, Marco; VENTURINI, Gabriella (Ed.). International disaster response law. Hague: T.M.C. Asser Press, 2012.

15 Ver: ORGANIZAÇÃO MARÍTIMA INTERNACIONAL. International Shipping Facts and Figures. Maritime Knowlegde Centre, 2012. p. 6.

16 ORGANIZAÇÃO MARÍTIMA INTERNACIONAL. International Shipping Facts and Figures. Maritime Knowlegde Centre, 2012. p. 6. 
o surgimento de situações jurídicas internacionais ou litígios transfronteiriços decorrentes de relações contratuais ou extracontratuais relacionados à navegação.

A bandeira do navio constitui um elemento de conexão importante para a solução de litígios transfronteiriços (cross-border litigations). Assim, o direito internacional privado buscar determinar a jurisdição competente e a lei aplicável aos conflitos em direito marítimo, dando maior segurança aos negócios jurídicos transnacionais. Ademais, a bandeira define a nacionalidade do navio e a jurisdição em que está registrado. Por seu turno, sob a perspectiva do comércio internacional, a nacionalidade do navio é essencial para garantir os direitos tarifários originários estabelecidos pelos países em acordos comerciais bilaterais ou multilaterais, tais como nas áreas de livre comércio, uniões aduaneiras ou nos mercados comuns.

Estudando a história do direito marítimo, a relação contratual era regida pela lei do lugar em que o ato era concluído (locus regit actum) ou no caso da responsabilidade extracontratual prevalecia a lei do pavilhão ou da nacionalidade do navio. De acordo com Carbone, esta "solution encore aujourd'hui acceptee, tout au moins dans les cas ou: i) le navire se trouve dans des espaces maritimes non soumis a la souverainete de l'Etat cotier et ii) il releve de la lex loci actus pour determiner la loi applicable a ces actes et faits". ${ }^{17}$

Os litígios transfronteiriços em direito marítimo podem decorrer tanto de obrigações contratuais quanto extracontratuais, em face de ser uma atividade de risco. Ibars afirma que a poluição marinha por navios pode ser classificada como voluntária ou acidental, e esta ocorre como consequência de um caso fortuito enquanto a primeira decorre das atividades normais do navio ou de práticas marítimas. ${ }^{18}$ As atividades cotidianas de navios e embarcações nem sempre provocam grandes derramamentos de hidrocarbonetos, por exemplo, mas nem por isso suas atividades diminuem o potencial de causar dano ao meio ambiente marinho.

A responsabilidade contratual decorre do inadimplemento de obrigações assumidas nos termos do contrato avençado. No direito marítimo, as obrigações

17 CARBONE, Sergio M. Conflits de lois en droit maritime. The Hague Academy of International Law, 2009. p. 201.

18 IBARS, Ingrid Sisteré. Corporate Social Responsibility in the Shipping Business. Master Thesis. Supervisor: Proshanto K. Mukherjee. Faculty of law Lund University. Sweden: Spring, 2013. contratuais podem surgir da compra e venda de navios, da contratação de serviços de transporte marítimo de mercadorias e de passageiros em um cruzeiro, do contrato de trabalho a bordo do navio, de contrato de direito reais sobre o navio dado em garantia, dos contratos de afretamento etc. Com fundamento no princípio da autonomia da vontade, as partes signatárias de um contrato podem escolher o direito aplicável, total ou parcialmente, e estabelecer uma cláusula arbitral em seus contratos comerciais ou um acordo arbitral para dirimir potenciais conflitos em direito marítimo.

Por seu turno, a responsabilidade extracontratual surge de uma relação não contratual na qual a pessoa, natural ou jurídica, que causar dano a outrem, tem a obrigação de reparar os prejuízos sofridos. $\mathrm{O}$ ato que causou o dano poderá ser lícito, ilícito ou por risco. De acordo como o artigo 186 do Código Civil (CC), aquele que, por ação ou omissão voluntária, negligência ou imprudência, violar direito e causar dano a outrem, ainda que exclusivamente moral, comete ato ilícito. Ademais, o artigo 187 do CC afirma que também comete ato ilícito o titular de um direito que, ao exercê-lo, excede manifestamente os limites impostos pelo seu fim econômico ou social, pela boa-fé ou pelos bons costumes.

Assim, o objetivo da responsabilidade civil consiste em "restabelecer situações abaladas por atos ilícitos por terceiros, como elemento essencial para a vida em sociedade". ${ }^{19}$ Nos termos do artigo 927 do CC, aquele que, por ato ilícito causar dano a outrem, fica obrigado a repará-lo independentemente de culpa, ou quando a atividade normalmente desenvolvida pelo autor do dano implicar, por sua natureza, risco para os direitos de outrem.

Com relação aos atos ilícitos nas relações privadas internacionais, aquelas que estão conectadas a dois ou mais ordenamentos jurídicos, o direito internacional privado busca estabelecer regras de direito aplicável à responsabilidade extracontratual por danos causados por navios ou embarcações, nacionais ou estrangeiros. Destaca-se, ainda, que no caso de dano ao meio ambiente marinho, a responsabilidade é objetiva, independentemente de culpa, e caberá ao navio poluidor a reparação do dano, objetivando principalmente a restituio in integrum e não apenas o pagamento de indenização pelos prejuízos.

19 ANTUNES, Paulo de Bessa. Dano ambiental: uma abordagem conceitual. Rio de Janeiro: Lumen Juris, 2000. p. 118. 


\subsection{A Nacionalidade dos navios}

As relações jurídicas em direito marítimo são complexas em função de sua própria natureza internacional. Embora haja discussão sobre a questão de se atribuir nacionalidade a coisas, este não é o objeto do presente trabalho, limitando-se apenas a discutir o tratamento jurídico dado ao navio. A ideia de nacionalidade dos navios "exprime conexão entre um dado conjunto de situações de que são sujeitos o proprietário, o armador, o comandante, a tripulação e os passageiros, entre outros, com alguma relação com o navio, e um determinado Estado" 20 . A nacionalidade do navio cria um vínculo jurídico-administrativo para determinar o lugar do registro de matrícula em um país e, consequentemente, o direito de arvorar a sua bandeira.

Em princípio, cada Estado é livre para definir os critérios para que um navio ou embarcação possa arvorar a sua bandeira ou o seu pavilhão, conforme dispõe ao artigo 91 da Convenção das Nações Unidas sobre Direito do Mar (CNUDM). Esta é uma regra de caráter geral que busca estabelecer regras uniformes no direito marítimo, bem como o direito do Estado de regular os bens que estão ou circulam em seu território.

O conceito de navio está relacionado à ideia de meio de transporte por água, destinado ao deslocamento de pessoas e mercadorias. Nos termos do artigo 11 da Lei 2180/54, considera-se "embarcação mercante toda construção utilizada como meio de transporte por água, e destinada à indústria da navegação, quaisquer que sejam as suas características e lugar de tráfego". Por seu turno, a Lei no 9.966/2000 define navio como "embarcação de qualquer tipo que opere no ambiente aquático, inclusive hidrofólios, veículos a colchão de ar, submersíveis e outros engenhos flutuantes", de acordo como o artigo $2^{\circ}, \mathrm{V}$. Contudo, no jogo do comércio internacional, o navio apresenta uma dimensão política com base no critério quantitativo de participação dos países na indústria da navegação. Nesse contexto, Agripino afirma que

[...] o navio, espécie do gênero embarcação, é a ferramenta principal desse setor relevante da economia mundial, no qual o Direito e a Economia devem na-

20 PINHEIRO, Luís de Lima. Temas de direito marítimo: o navio em direito internacional. Disponível em: <http://www.oa.pt/ upl/\%7Ba7992dcf-4940-4738-acd7-c9fc7e4e58c1\%7D.pdf>. Acesso em: 12 fev. 2014. vegar juntos para que haja o seu desenvolvimento, mas para que isso ocorra é preciso que as instituições funcionem com eficácia, tendo como marco fundamental a Constituição Federal. ${ }^{21}$

À luz do direito brasileiro, é por meio do registro da propriedade que se estabelece a nacionalidade de embarcações, conforme determina a Lei 7.652/1988, que dispõe sobre o registro da propriedade marítima, dos direitos reais e demais ônus e registro do armador. Nesse contexto, o Tribunal Marítimo decidiu que

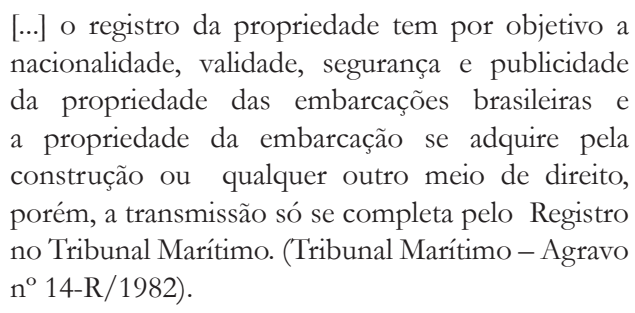

Destaca-se, ainda, o controle administrativo dos Estados sobre embarcações nacionais e estrangeiras, por intermédio de suas autoridades locais, para realizar vistorias em navios estrangeiros a fim de se examinar se estes estão cumprindo os termos da Convenção MARPOL $73 / 78$.

Contudo, de acordo com os estudos realizados pela Conferência das Nações Unidas para Comércio e Desenvolvimento (UNCTAD),

just as today most ships fly a flag that is different
from that of the owner's nationality, owners are
increasingly locating their companies in third
countries/economies, adding a possible third
dimension to the nationality of a ship and its
owner. A ship's nationality is defined by the nation
whose flag it flies, while the owner may have a
different nationality, and the owner's company that
controls the vessel may be based in a third country/
economy. These different dimensions render the
historical concept of "national fleets" more blurred
and less meaningful.

Atualmente, o Brasil ${ }^{23}$ é o país que possui a maior frota de navios da América Latina e Caribe, seguido por Venezuela e Chile, em termos localização de proprieda-

21 CASTRO JUNIOR, Osvaldo Agripino de. Principais aspectos do direito marítimo e sua relação com a Lex Mercatoria e Lex Maritima. Revista Sequência Estudos Jurídicos e Políticos, v. 31, n. 61, p. 195-225, dez. 2010. p. 203.

22 CONFERÊNCIA DAS NAÇÕES UNIDAS SOBRE COMÉRCIO E DESENVOLVIMENTO. Review of maritime transport. Geneva: United Nations Publication, 2014. p. 32.

23 CONFERÊNCIA DAS NAÇÕES UNIDAS SOBRE COMÉRCIO E DESENVOLVIMENTO. Review of maritime transport. Geneva: United Nations Publication, 2014. p. 39. 
de efetiva (beneficial ownership location), que é diferente do critério da nacionalidade do proprietário efetivo (ultimate owner's nationality).

Os navios ou embarcações têm direito de arvorar a bandeira brasileira quando inscritas no registro de propriedade marítima, de propriedade de pessoa física residente e domiciliada no país ou de empresa brasileira; ou sob contrato de afretamento a casco nu, por empresa brasileira de navegação, condicionado à suspensão provisória de bandeira no país de origem, de acordo o com o artigo $3^{\circ}$ da Lei 9.432/1997. O contrato de afretamento a casco nu estabelece ao afretador os direitos de posse uso e controle da embarcação, por tempo determinado, incluindo o direito de designar o comandante e a tripulação. Além disso, a lei estabelece cria o sistema de registro especial brasileiro - (REB), regulamentado pelo Decreto n ${ }^{\circ} 2.256 / 1997$, de caráter suplementar ao registro de propriedade marítima e de competência do Tribunal Marítimo. O REB autoriza o registro das embarcações estrangeiras afretadas a casco nu, com suspensão de bandeira de origem.

Por sua vez, o Código de Bustamante (artigos 274 a 284) afirma que a lei do pavilhão regula as formas de publicidade requeridas para a transmissão da propriedade de um navio e que a nacionalidade dos navios se prova pela patente de navegação e a certidão do registro, e tem a bandeira como sinal distintivo aparente. Além disso, São de ordem pública internacional as regras sobre a nacionalidade dos proprietários de navios e dos armadores, assim como dos oficiais e da tripulação.

O direito marítimo é um direito complexo na medida em que nem sempre há correlação do proprietário efetivo do navio com a bandeira. $\mathrm{O}$ direito do pavilhão pode ter origem contratual de afretamento, atribuindo o direito, uso e controle sobre a embarcação. Contudo, isso não exime a reponsabilidade da empresa estrangeira, nem da empresa brasileira contratante, respondendo ambos solidariamente em caso de dano.

Embora haja a possibilidade de o navio arvorar mais de uma bandeira, a CNUDM restringe a utilização segundo as conveniências de seus proprietários perante exercício de direitos contra terceiros, conforme artigo 92. De acordo com o estatuto dos navios, a norma geral é que os navios naveguem sob a bandeira de um só Estado e, somente em casos excepcionais previstos expressamente em tratados internacionais ou no texto da própria convenção. Em alto-mar, o navio está sob a jurisdição exclusiva do Estado da bandeira ou do pavilhão. Limita o direito de mudar de bandeira durante uma viagem ou em porto de escala, com exceção de transferência efetiva da propriedade ou de mudança de registo.

Agripino destaca que os navios de bandeira de conveniência, além de serem os maiores poluidores do meio ambiente, por não se submeter ao rigor fiscalizatório, são mais propensos a serem usados pelos terroristas. Para aumentar a segurança no setor, é necessária uma ação cooperativa multilateral ${ }^{24}$. No mesmo sentido, Martins assevera que

Os Registros Abertos de Bandeiras de Conveniência
(BDC) se caracterizam por oferecer total facilidade
para registro, incentivos de ordem fiscal, não
imposição de vínculo entre o Estado de Registro
e o navio. Ademais, tais Estados não exigem e nem
fiscalizam, com o devido rigor, o cumprimento e
a adoção das normas e regulamentos nacionais
ou internacionais sobre as embarcações neles
registradas. Simultaneamente às vantagens
econômicas oferecidas por tais registros, ainda se
elencam legislações e regulamentos menos severos
sobre segurança e equipamento de bordo, que não
exigem nenhum vínculo entre Estado de Registro
e navio.

Observa-se, ainda, que outro fator que atinge o mercado petrolífero e de transportes é a generalização das bandeiras de conveniência, adotadas como estratégia de redução de custos e de competitividade. ${ }^{26}$

No que tange aos acidentes causados por transporte marítimo em território brasileiro, o relatório da CETESB sobre ocorrências envolvendo petróleo e derivados no Brasil, no período de 1960 a 2012 informa que foram registrados quarenta e dois casos de vazamento por petróleo e seus derivados (lançamento no meio ambiente marinho de metanol, óleo lubrificante, nafta e de mistura oleosa). Ainda segundo o relatório revela que a maior parte desses acidentes foi causada por transportes marítimos, (acidentes de navegação por motivos diversos), representando $42 \%$ do total de acidentes (18

24 CASTRO JUNIOR, Osvaldo Agripino de. Principais aspectos do direito marítimo e sua relação com a Lex Mercatoria e Lex Maritima. Revista Sequência Estudos Jurídicos e Políticos, v. 31, n. 61, p. 195-225, dez. 2010. p. 204.

25 MARTINS, Eliane M. Octaviano. Segurança Marítima vis-à- vis Desenvolvimento Sustentável. Revista CEJ, Brasília, ano 11, n. 37, p. 103-107, abr./jun. 2007. p. 104.

26 MARTINS, Eliane M. Octaviano. Segurança Marítima vis-à- vis Desenvolvimento Sustentável. Revista CEJ, Brasília, ano 11, n. 37, p. 103-107, abr./jun. 2007. p. 104 
acidentes), sendo a maioria em áreas portuárias, por navios petroleiros. Apesar disso, o relatório constatou uma diminuição das ocorrências envolvendo transporte marítimo com petroleiros. Esses acidentes foram julgados pela justiça federal, órgão cuja competência é definida em razão da aplicação do tratado internacional sobre poluição por óleo, conforme dispõe ao artigo 109, III, da CF.

\subsection{Lei aplicável à responsabilidade extracontratual por danos ambientais em direito marítimo}

Determinar a lei aplicável é uma das tarefas do direito internacional privado para buscar soluções aos litígios transfronteiriços. No direito marítimo, estabelecer apenas como regra de conexão a aplicação do princípio da lei do pavilhão ou bandeira pode não ser a mais adequada às relações privadas internacionais, considerando-se que o evento poderá ocorrer em diferentes espaços limitados pelo direito internacional: mar territorial, zona econômica exclusiva ou alto-mar, por exemplo.

O problema da regra da lei da bandeira é que muitas vezes a lei aplicável não tem conexão com o caso. Cheshire adverte que a regra de conexão da lei da bandeira não funciona quando houver uma colisão entre dois navios arvorando diferentes bandeiras e os navios frequentemente arvoram bandeiras de conveniência e, consequentemente, a lei aplicável poderia ser a do Panamá, apesar de as partes e o evento não terem conexão com o país. ${ }^{27}$

Os principais problemas de direito marítimo estão relacionados às bandeiras de conveniência, nas quais as empresas de navegação buscam obter vantagens oferecidas pelo Estado da bandeira, como benefícios tributários e as de encargos trabalhistas. Isso traz problema para as práticas leais ao comércio marítimo internacional e é por isso que a CNUDM limita os direitos dos navios que arvoram duas bandeiras simultaneamente.

O atual código comercial Lei $n^{\circ} 556 / 1850$, que regula o comércio marítimo, não apresenta regras claras sobre a lei aplicável no caso de responsabilidade extracontratual. O artigo 529 assevera que o capitão é responsável por todas as perdas e danos que, por culpa sua,

27 CHESHIRE, Peter North; FAWCETT, James; CARRUTHERS, Janeen. Cheshire, North \& Fawcett: Private International Law. Oxford: OUP, 2008. p. 859. omissão ou imperícia, sobrevierem ao navio ou à carga; sem prejuízo das ações criminais a que a sua malversação ou dolo possa dar lugar. No caso de dano causado por abalroação, o Título XI estabelece regras específicas sobre responsabilidade. De acordo com o artigo 749 , sendo um navio abalroado por outro, o dano inteiro causado ao navio abalroado e à sua carga será pago por aquele que tiver causado a abalroação, se esta tiver acontecido por falta de observância do regulamento do porto, imperícia, ou negligência do capitão ou da tripulação; fazendo-se a estimação por árbitros. No caso de a abalroação ocorrer em alto-mar e o navio abalroado for obrigado a procurar porto de arribada para poder consertar, e se perder nessa derrota, a perda do navio presume-se causada pela abalroação, nos termos do artigo 751 do Código Comercial.

Observa-se que o código não se estabelece a lei aplicável em caso de dano, mas apenas se determina a responsabilidade do navio que causou o dano: aplica-se a lei da bandeira do navio causador do dano ou a lei local onde o dano ocorreu?

A Lei de Introdução às Normas de Direito Brasileiro é omissa quanto à lei aplicável às obrigações não contratuais, estabelecendo apenas regras de conflitos para as obrigações contratuais, aplicando-se a regra do locus regit actum e da lex loci celebrationis, ou seja, a lei do país onde o ato for constituído, conforme dispõe o artigo $9^{\circ}$.

A Emenda na Comissão no 56/2012 ao novo Projeto de Lei no 1.572/2011, que tramita na Câmara dos Deputados, visa instituir o novo código comercial e a ele foi pedida a inclusão um novo livro relativo ao Direito Marítimo. Este livro de lei dispõe especificamente sobre a lei aplicável ao direito marítimo no título II, que trata do âmbito de aplicação do Direito Comercial Marítimo, na qual dispõe Para os efeitos desse Código, consideram-se águas sob jurisdição nacional as águas compreendidas pelo mar territorial, as águas situadas nos limites da Zona Econômica Exclusiva e, além desta, as águas sobrejacentes à Plataforma Continental, conforme artigo 12.

Além disso, o projeto estabelece que os fatos e atos originados em embarcações que produzirem efeitos no Brasil são regidos pelas leis brasileiras, ainda que iniciados no território estrangeiro ou em alto-mar (artigo 14). Já os fatos e atos provenientes de embarcações que tiverem início em águas sob jurisdição nacional regem-se pelas leis brasileiras, respeitadas as leis do Estado 
em que produzirem efeito, conforme artigo 15. Por sua vez, os direitos reais e os privilégios de ordem privada sobre embarcações regem-se pela lei de sua nacionalidade (artigo 16). Com relação às medidas assecuratórias de direito, estas são reguladas pela lei do país onde se encontrar a embarcação, conforme dispõe o artigo 17 do projeto. Quanto às avarias, regulam-se pela lei brasileira quando a carga se originar ou se destinar ao Brasil ou for transportada sob o regime de trânsito aduaneiro (artigo 18).

Observa-se que o Código Comercial atual além não trazer disposições claras acerca da lei aplicável aos acidentes de navegação, dispõe apenas sobre a responsabilidade civil extracontratual fundada apenas no ilícito civil de natureza patrimonial do proprietário navio pela perda de sua propriedade, responsabilizando o navio causador do dano. Ressalta-se que, para resolver os conflitos, as partes podem recorrer à arbitragem comercial.

Já o novo projeto de lei esclarece as regras sobre lei aplicável às relações privadas internacionais decorrentes das atividades marítimas. Primeiro estabelece a regra de conexão lex loci, aplica-se a lei brasileira para os fatos e os atos ocorridos em águas sob jurisdição nacional. Contudo, reconhece a aplicação extraterritorial da lei do Estado, como por exemplo, no caso de aplicação de sanções administrativas à tripulação do navio, ainda que o fato ou ato tenha ocorrido no exterior. No que tange aos direitos reais e de hipoteca, a regra de conexão é a lexpatriae, ou seja aplica-se a lei da nacionalidade do navio ou embarcação, conforme dispõe atualmente o artigo $3^{\circ}$ da Lei no 9.432/1997e do Decreto no 2.256/1997.

Assim, no caso de responsabilidade extracontratual por danos causados por embarcações, a regra geral sobre lei aplicável é a da lex fori quando o ato ilícito ocorrer em águas brasileiras.

O projeto ainda trata da responsabilidade do armador, na qual atribui responsabilidade extracontratual por danos ambientais, conforme determina o projeto no artigo 147:

Art. [147]. As disposições relativas à limitação da responsabilidade não são aplicáveis:

I - às reclamações derivadas de operações de salvamento da própria embarcação ou de contribuição por avaria grossa;

II - às reclamações por dano ao meio ambiente;

III - às despesas de remoção de destroços;
IV - às reclamações por danos nucleares, quando proibida a limitação de responsabilidade;

$\mathrm{V}$ - aos créditos trabalhistas do capitão e membros da tripulação ou de qualquer outro empregado do armador que se encontre a bordo da embarcação ou cujas funções se relacionem com a sua operação (grifo nosso).

A previsibilidade das regras aplicáveis aos conflitos de leis no direito marítimo dá maior segurança jurídica, incluindo não apenas aquelas previsíveis nas obrigações contratuais, mas por se tratar de atividades de risco, há possibilidade de responsabilização extracontratual por danos patrimoniais e ao meio ambiente.

Em alto-mar, a regra geral é da lei da bandeira ou do pavilhão do causador do dano. Contudo, há, ainda, a necessidade de se aperfeiçoar os instrumentos de responsabilidade civil em alto-mar, que como bem afirma Soares "a poluição do meio ambiente por lançamento deliberado no alto-mar tem sido a forma usual de os Estados e empresas desfazerem-se dos resíduos industriais, urbanos e hospitalares, da maneira menos custosa do que destruí-los em terra ou nela manterem em depósito"28.

A regra de conexão para se determinar a lei aplicável à poluição marinha causada por navios é a lex loci damni. Na prática, busca-se uma proteção mais efetiva do meio ambiente marinho, com fundamento nos princípios da precaução e do poluidor-pagador e, também, em razão da natureza peculiar da indústria de navegação ser considerada de risco, levando-se em conta a carga transportada, potencializando em graus o risco de danos ao meio marinho.

Portanto, o poluidor tem a obrigação de recuperar e/ou indenizar pelos danos causados por navios ao meio ambiente marinho, de acordo com a Política $\mathrm{Na}$ cional do Meio Ambiente ${ }^{29}$, aplicando-se a lei brasileira e independentemente da nacionalidade do navio.

\subsubsection{Convenções internacionais}

No caso de danos ambientais causados por navios, as convenções internacionais não estabelecem regras

28 SOARES, Guido Fernandes Silva. Direito internacional do meio ambiente: emergência, obrigações e responsabilidades. São Paulo: Atlas, 2001. p. 226.

29 Ver artigo $4^{\circ}$, BRASIL. Lei no 6.938, de 31 de agosto de 1981. Disponível em: <http://www.planalto.gov.br/ccivil_03/Leis/ L6938.htm>. Acesso em: 07 ago. 2015. 
sobre o direito aplicável. Deduz-se, portanto, que in dubio pro natura, com fundamento no princípio da precaução do direito ambiental. Assim aplica-se a lei brasileira quando o dano correr em mar territorial, as águas situadas nos limites da Zona Econômica Exclusiva e, além desta, as águas sobrejacentes à Plataforma Continental, com fundamento na lex loci damni. Nesse sentido, de acordo com Bernasconi,

\begin{abstract}
A lei do lugar do dano (lex damni) também pode ser protetiva aos interesses do requerente na medida em que, muitas vezes, correspondem ao local de sua residência e ao lugar onde seu imóvel está localizado. Esta também se justifica pelo fato de que a principal função da lei de responsabilidade é a reparação de uma lesão e não a punição de uma falta, tanto que a responsabilidade objetiva desempenha um papel importante quando o ambiente é lesado. ${ }^{30}$
\end{abstract}

No âmbito doméstico, a Lei $n^{\circ} 9.966 / 2000$ estabelece os princípios básicos a serem obedecidos na movimentação de óleo e outras substâncias nocivas ou perigosas em portos organizados, instalações portuárias, plataformas e navios em águas sob a jurisdição nacional. Esta lei é aplicável aos casos de poluição por óleo quando ausentes os pressupostos da aplicação da Convenção Internacional para a Prevenção da Poluição Causada por Navios (Convenção MARPOL 73/78), conforme dispõe o parágrafo único do artigo $1^{\circ}$. Assim, a lei doméstica tem natureza complementar às Convenções internacionais MARPOL 73/78, CLC/69 e OPRC/90.

Ademais, a jurisprudência dos tribunais estatais, federais e do Tribunal do Mar demonstra aplicação tanto das normas internacionais uniformizadoras de direito marítimo quanto das normas de direito interno para responsabilização por danos ao meio ambiente marinho. A dicotomia entre o direito internacional e o direito interno tem engendrado conflitos de competência entre a justiça federal e a justiça estadual. Em alto-mar, os navios estão sujeitas a regra da lei da bandeira ou do pavilhão, em conformidade com o artigo 92 da CNUDM.

\subsubsection{Direito comunitário europeu}

No âmbito do direito internacional privado comunitário, o Regulamento (CE) no 864/2007 do Parlamento

30 BERNASCONI, Christophe. Civil liability resulting from transfrontier environmental damage: a case for the Hague Conference? Disponível em: <http://www.hcch.net/upload/wop/gen_pd8e.pdf>. Acesso em: 14 ago. 2014
Europeu e do Conselho da União Europeia (Regulamento Roma II) estabelece as regras de lei aplicável às obrigações extracontratuais em geral.

O preâmbulo do regulamento em seu parágrafo 24 define danos ambientais como a alteração adversa de um recurso natural, como a água, o solo ou o ar, ou a deterioração do serviço de um recurso natural em benefício de outro recurso natural ou do público, ou a deterioração da variabilidade entre organismos vivos.

De acordo com o artigo $7^{\circ}$ relativo a danos ambientais,

A lei aplicável à obrigação extracontratual que decorra de danos ambientais ou de danos não patrimoniais ou patrimoniais decorrentes daqueles é a que resulta da aplicação do ${ }^{\circ} 1$ do artigo $4^{\circ}$, salvo se a pessoa que requer a reparação do dano escolher basear o seu pedido na lei do país onde tiver ocorrido o dano.

Por sua vez, o artigo $4^{\circ}$ dispõe sobre a regra geral:

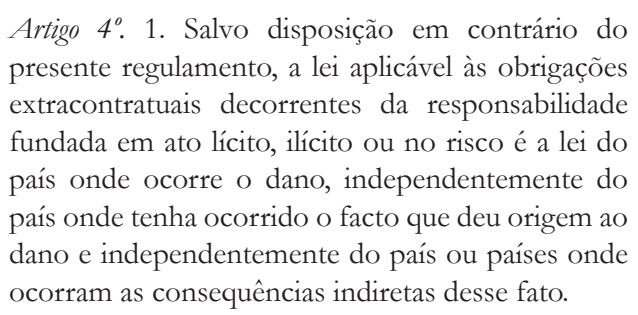

Desse modo, as regras estão claras quanto à lei aplicável aos danos ocorridos em águas territoriais dos Estados membros da União Europeia. Entretanto, o problema reside em se determinar a lei aplicável em alto-mar, considerando as bandeiras de conveniência, uma vez que nem sempre têm conexão com a poluição marinha. Como afirma Cheshire, a identificação da lei aplicável por danos ocorridos em alto-mar não é uma questão fácil. ${ }^{31}$

\subsection{Obrigações extracontratuais: jurisdição e competência em acidentes marítimos}

A competência judicial internacional estabelece critérios para se conhecer os litígios transfronteiriços. Com fundamento na soberania estatal, cada país define os critérios de competência internacional, concorrente ou exclusiva, nos limites de seu território. A eficácia extraterritorial dos atos judiciais se baseia no princípio

31 CHESHIRE, Peter North; FAWCET'T, James; CARRUTHERS, Janeen. Cheshire, North \& Fawcett. Private International Law. Oxford: OUP, 2008. p. 860. 
da cooperação jurídica internacional. Nos casos de responsabilidade extracontratual em direito marítimo, qual o foro competente para resolver os litígios transfronteiriços: domicílio do réu, o lugar onde tiver de ser cumprida a obrigação de reparar o dano ou o lugar do fato danoso?

Há uma pluralidade de fontes normativas sobre questões referentes às obrigações extracontratuais tanto de direito interno (considerando os diversos ordenamentos jurídicos) quanto em direito internacional público e em direito internacional privado. Os efeitos dos danos plurilocalizados podem atingir tanto pessoas quanto bens conectados a diversos ordenamentos jurídicos, seja pelo estatuto pessoal seja pelo objeto ou pelo ato ou fato jurídico.

Para se estudar a jurisdição e a competência para julgar a responsabilidade civil por danos causados por navios ou embarcações ao meio ambiente marinho, deve-se ter em conta se o fato ocorreu em águas territoriais ou em águas internacionais.

\subsection{1. Águas territoriais}

As águas territoriais são aquelas que estão sob o domínio do Estado, e ao direito marítimo compete estabelecer os regimes jurídicos especiais sobre os espaços marítimos. A Convenção das Nações Unidas sobre Direito do Mar (CNUDM) afirma que a soberania do Estado costeiro estende-se além do seu território e das suas águas interiores e, no caso de Estado arquipélago, das suas águas arquipelágicas, a uma zona de mar adjacente designada pelo nome de mar territorial. Essa soberania estende-se ao espaço aéreo sobrejacente ao mar territorial, bem como ao leito e ao subsolo desse mar, conforme dispõe o artigo $2^{\circ}$ da CNUDM.

O Estado exerce, ainda, direito de soberania para fins de exploração e aproveitamento, conservação e gestão dos recursos naturais, vivos ou não vivos das águas sobrejacentes ao leito do mar, do leito do mar e seu subsolo, e no que se refere a outras atividades com vista à exploração e aproveitamento da zona para fins econômicos e jurisdição sobre a zona econômica exclusiva para a proteção e preservação do meio marinho, de acordo como o artigo $56 \mathrm{da}$ CNUDM.

Além disso, o Estado costeiro exerce direitos de soberania sobre a plataforma continental para efeitos de exploração e aproveitamento dos seus recursos naturais, conforme disposto no artigo 77 da CNUDM. Já o alto-mar é aberto a todos os Estados costeiros e sem litoral, tendo o direito de fazer navegar os navios que arvorem sua bandeira.

Nesse contexto, a definição dos espaços marinhos no plano internacional foi importante para se determinar as competências judiciais, administrativas e tributárias sobre o direito de navegação. Igualmente, reconhece a soberania territorial dos Estados sobre as águas interiores, incluindo o mar territorial, plataforma continental e zona econômica exclusiva.

O princípio da precaução engendra políticas públicas para evitar o dano. Os instrumentos de fiscalização e monitoramento das atividades marítimas são importantes, considerando a potencialidade do risco de poluição marinha em face do conteúdo da carga transportada. Nesse sentido, a Lei $n^{\circ} 9.966 / 2000^{32}$ estabelece regras para a prevenção, o controle e a fiscalização da poluição causada por lançamento de óleo e outras substâncias nocivas ou perigosas em águas sob a jurisdição nacional. Essa lei classifica, ainda, as substâncias nocivas ou perigosas em quatro categorias de $\mathrm{A}$ a $\mathrm{D}$, do mais alto ao mais baixo em grau de risco, tanto para a saúde das pessoas como para o ecossistema aquático, em conformidade com as normas estabelecidas pela Convenção MARPOL 73/78.

Por sua vez, o Decreto $n^{\circ} 8.127 / 2013$, que instituiu o Plano Nacional de Contingência para Incidentes de Poluição por Óleo em Águas sob Jurisdição Nacional, define águas marítimas brasileiras como todas aquelas sob a jurisdição nacional que não sejam interiores. São águas marítimas:

$$
\begin{aligned}
& \text { a) as águas abrangidas por uma faixa de doze milhas } \\
& \text { marítimas de largura, medidas a partir da linha } \\
& \text { de base reta e da linha de baixa-mar, conforme } \\
& \text { indicação das cartas náuticas de grande escala, } \\
& \text { reconhecidas oficialmente no Brasil - mar territorial; } \\
& \text { b) as águas abrangidas por uma faixa que se estende } \\
& \text { das doze às duzentas milhas marítimas, contadas a } \\
& \text { partir das linhas de base que servem para medir o } \\
& \text { mar territorial, que constituem a zona econômica } \\
& \text { exclusiva; e } \\
& \text { c) as águas sobrejacentes à plataforma continental, } \\
& \text { quando esta ultrapassar os limites da zona } \\
& \text { econômica exclusiva. }
\end{aligned}
$$

32 Regulamentada pelo Decreto no 4136/2002, que dispõe sobre a especificação das sanções aplicáveis às infrações às regras de prevenção, controle e fiscalização da poluição causada por lançamento de óleo e outras substâncias nocivas ou perigosas em águas sob jurisdição nacional. 
A harmonização entre o direito interno e o direito internacional é essencial para dar maior segurança jurídica às atividades de navegação. Desse modo, nota-se que as normas internas e internacionais reconhecem a jurisdição dos Estados sobre as águas territoriais e, consequentemente, a competência das autoridades administrativas (fiscalizatórias) e judiciais no caso de acidentes marítimos e incidentes da navegação, incluindo aqueles que causarem danos ao meio ambiente marinho.

À luz do direito brasileiro, a regra de conexão para determinar a competência internacional sobre responsabilidade civil extracontratual é a do forum damni, isto é, o tribunal do Estado onde ocorreu o dano. O Código de Processo Civil (CPC) em matéria de competência judicial internacional estabelece que:

Art. 88. É competente a autoridade judiciária brasileira quando:

I - o réu, qualquer que seja a sua nacionalidade, estiver domiciliado no Brasil;

II - no Brasil tiver de ser cumprida a obrigação;

III — a ação se originar de fato ocorrido ou de ato praticado no Brasil. (grifo nosso).

Por seu turno, o Novo CPC -Lei no 13.105/2015, no capítulo referente aos limites da jurisdição nacional, estabelece que:

Art. 21. Compete à autoridade judiciária brasileira processar e julgar as ações em que:

I - o réu, qualquer que seja a sua nacionalidade, estiver domiciliado no Brasil;

II - no Brasil tiver de ser cumprida a obrigação;

III - o fundamento seja fato ocorrido ou ato praticado no Brasil. (grifo nosso).

Ademais, a jurisdição civil é regida pelas normas processuais brasileiras, ressalvadas as disposições específicas previstas em tratados, convenções ou acordos internacionais de que o Brasil seja parte, nos termos do artigo 13 do Novo CPC. Destarte, com fundamento na norma processual, observa-se que, na jurisprudência brasileira, aplica-se a regra do forum damni, isto é, a autoridade judicial brasileira é competente para julgar os casos de poluição marinha em águas territoriais (mar territorial, plataforma continental e zona econômica exclusiva).

Por sua vez, o Tribunal Marítimo, criado em 1931, é órgão administrativo vinculado ao Ministério da Marinha e auxiliar do poder judiciário, nos termos do artigo $1^{\circ}$ da Lei no $2.180 / 1954$. De acordo com o artigo 10, o Tribunal Marítimo exerce jurisdição sobre:

a) embarcações mercantes de qualquer nacionalidade, em águas brasileiras;

b) embarcações mercantes brasileiras em alto-mar, ou em águas estrangeiras;

c) embarcações mercantes estrangeiras, em altomar, nos casos de estarem envolvidas em qualquer acidente marítimo ou incidente de navegação, no qual tenha pessoa física brasileira perdido a vida ou sofrido ferimentos graves, ou que tenham provocado danos graves a navios ou a instalações brasileiras ou no meio marinho, de acordo com as normas do Direito Internacional;

$[\ldots]$

e) os marítimos estrangeiros, em território ou águas territoriais brasileiras;

l) toda pessoa jurídica ou física envolvida, por qualquer forma ou motivo, em acidente ou fato da navegação, respeitados os demais instrumentos do Direito Interno e as normas do Direito Internacional.

Com relação à competência internacional, o Tribunal Marítimo é competente para julgar tanto acidentes de navegação, tais como, naufrágio, encalhe, colisão, abalroação, água aberta, explosão, incêndio, arribada, alijamento e avaria, como fatos da navegação, tais como mau aparelhamento ou a impropriedade da embarcação, a alteração da rota, má estivação da carga entre outros enumerados no artigo $14 .^{33}$

Observa-se que a jurisdição sobre questões em águas interiores não é absoluta, mas concorrente. A jurisdição é exclusiva para exercer o poder de polícia, tais como a fiscalização e aplicação de multas a navios estrangeiros que agem contrariamente às normas brasileiras. Por outro lado, a jurisdição pode ser concorrente, ainda que se trate de coisa julgada em relação às obrigações contratuais. Em 1935, o caso da Cia. de Navegação Lóide Brasileiro, proprietária do navio Campos, foi condenada por tribunal arbitral argentino a ressarcir os danos causados ao navio inglês Westminster em razão do abalroamento entre ambos, em águas territoriais argentinas. $\mathrm{O}$ laudo concluiu pela culpa do capitão do navio brasileiro. Nesse contexto, o Tribunal Marítimo Administrativo (TMA) em nota no Processo no 186 (1938) nesse caso ementou:

33 Importante destacar que s decisões do Tribunal Marítimo, quanto a matéria técnica referente aos acidentes e fatos de navegação têm valor probatório e se presumem certas, sendo porém suscetíveis de reexame pelo Poder Judiciário Art. 18 
Jurisdições concorrentes. Embora se trate de coisa julgada, nenhum dispositivo legal, ou regra de direito internacional, veda ao Estado o direito de examinar e punir administrativamente os atos funcionais de seus jurisdicionados no estrangeiro. ${ }^{34}$

De acordo com essa decisão, o Tribunal Marítimo reconheceu a competência do tribunal arbitral argentino para os fatos ocorridos em seu mar territorial, reconheceu a responsabilidade do capitão do navio brasileiro para efeitos de reparação civil, de caráter meramente patrimonial pelos danos materiais causados ao lesado. Contudo, entendeu que, em virtude da lei do pavilhão, o tribunal brasileiro era também competente para julgar e aplicar as penalidades de ordem administrativa ao causador do acidente, o capitão ou qualquer membro de sua tripulação.

$\mathrm{Na}$ União Europeia, o artigo $7^{\circ}$, parágrafo $2^{\circ}$, do Regulamento (EU) no 1215/2012 do Parlamento Europeu e do Conselho relativo à competência judiciária, ao reconhecimento e à execução de decisões em matéria civil e comercial estabelece que as pessoas domiciliadas num Estado-membro podem ser demandadas em outro Estado-membro. O regulamento dispõe sobre competências especiais e, em relação à matéria extracontratual atribui competência ao tribunal do lugar onde ocorreu o dano ou poderá ocorrer o fato danoso. Nesse sentido, Caravaca afirma que este artigo outorga competência aos tribunais de um determinado lugar, e não somente a dos tribunais de um Estado-membro em seu conjunto. Não obstante, podem ocorrer casos em que a competência dos tribunais de um Estado-membro seja clara, mas não seja possível identificar com precisão o órgão judicial competente desse Estado. É o caso de ilícitos verificados a bordo de navios e aeronaves. ${ }^{35}$

Nessa seara, a Emenda na Comissão no 56/2012 do Projeto de Lei $n^{\circ}$ 1.572/2011 sobre Direito Comercial Marítimo, que tramita na Câmara dos Deputados, propõe a criação de regras especiais de Direito Processual Marítimo. Com relação à competência internacional, sem prejuízo das normas gerais de processo civil, o artigo 229 determina a competência da autoridade judiciária brasileira com relação a embarcações brasileiras, em qualquer lugar que se encontrem; para conhecer de

34 TRIBUNAL MARÍTIMO ADMINISTRATIVO. Processo $n^{\circ}$ 186/1938. Disponível em: <https://www.mar.mil.br/tm/download/anuario/1936_1940/186.pdf>. Acesso em: 15 fev. 2014.

35 CARAVACA, Alfonso-Luis Calvo; GONZÁLEZ, Javier Carrascosa. Derecho internacional privado. 14. ed. Granada: Comares, 2014. v. 1. p. 1.125 . ações de embargo de embarcação ${ }^{36}$ estrangeira que se encontre em águas jurisdicionais brasileiras, independentemente do local de cumprimento da obrigação, ainda que esta não se origine de fato ocorrido ou de ato praticado no Brasil; e com relação às demais pretensões envolvendo embarcações estrangeiras, quando se encontrarem em águas jurisdicionais brasileiras.

\subsection{2. Águas estrangeiras}

As águas estrangeiras são consideradas aquelas que estão sujeitas à jurisdição do Estado estrangeiro, tendo competência legislativa e jurisdicional. De acordo com Cheshire, os tribunais ingleses tradicionalmente têm aplicado uma abordagem literal do local do dano, quando o ato ou fato ocorrer em águas territoriais. ${ }^{37}$

Destarte, observa-se que a regra geral para estabelecer competência para julgar em águas estrangeiras é forum damni estrangeira. Assim, nos casos de uma empresa de navegação brasileira ter causado dano em águas marítimas internas dever acionar os instrumentos da cooperação jurídica internacional para dar eficácia extraterritorial aos atos judicias do tribunal competente. Nesse caso, a carta rogatória é um dos principais instrumentos para comunicação de atos e obtenção de provas no exterior nos casos de litígios transfronteiriços por danos causados por transportes marítimos.

$\mathrm{Na}$ Carta Rogatória n $1.433 / \mathrm{BE}$, a autoridade belga formulou um pedido de cooperação jurídica internacional para que se procedesse à inquirição da Empresa de Navegação Elcano S/A, a respeito da acusação de violação da lei relativa à proteção do meio marinho ocorrido no mar territorial belga (lex loci dammi). Apesar da impugnação sob a alegação de ofensa à ordem pública pela empresa brasileira, o Superior Tribunal de Justiça (STJ) acolheu a impugnação apenas parcialmente para solicitar ao juiz belga (rogante) o questionário das perguntas a serem formuladas à empresa e a cópia da legislação mencionada no pedido rogatório, notadamente à relativa a responsabilização penal da pessoa jurídica. Ao

36 O Embargo de Embarcação, definido no artigo 231 do Projeto de Lei, refere-se à tutela judicial de urgência, que visa impedir a saída de embarcações, brasileiras ou estrangeiras, das águas jurisdicionais brasileiras. O objetivo é caucionar a dívida, nos termos da lei da embarcação estrangeira e quando o navio nacional não disponha de outro patrimônio no país.

37 CHESHIRE, Peter North; FAWCETT, James; CARRUTHERS, Janeen. Cheshire, North \& Fawcett: Private International Law. Oxford: OUP, 2008. p. 859. 
agravo regimental da carta rogatória foi negado provimento em face de a diligência não ofender a soberania nacional e nem a ordem pública e que "os temas que a empresa brasileira pretende ver analisados dizem respeito ao mérito da controvérsia, insuscetível de apreciação no procedimento rogatório". Ao Superior Tribunal de Justiça não compete analisar causa a ser decidida no exterior (forum damni).

Desse modo, observa-se que a regra geral para a competência internacional para julgar os casos de responsabilidade extracontratual em caso de poluição marinha é a regra do forum damni. Nessa diretriz, Caravaca sustenta que “o tribunal que corresponde ao 'lugar do dano' é um tribunal que pode devolver seu trabalho jurisdicional de maneira efetiva e real, com qualidade jurídica e a um custo reduzido, isto é, de maneia diferente". ${ }^{38}$

Em consequência, o reconhecimento da competência para julgar casos de responsabilidade civil extracontratual por danos marinhos é essencial para facilitar o reconhecimento e homologação de sentença estrangeira e assegurar seus efeitos extraterritoriais.

\subsection{3 Águas internacionais}

A complexidade do direito marítimo é mais acentuada quando ocorrem atos lícitos, ilícitos ou por riscos causados por transportes marítimos, seja a bordo do navio, seja por atos externos causados pelo navio. Embora os navios em mar internacional estejam sujeitos à regra da lei da bandeira ou do pavilhão, essa regra não se entende a competência internacional, uma vez que nem sempre é a regra que mais se aproxima do caso. No caso de poluição marinha, a responsabilidade objetiva é do poluidor-pagador. Mas se o navio arvorar duas ou mais bandeiras de conveniência, torna-se mais difícil a sua responsabilização, assim como os navios piratas, por exemplo.

Por seu turno, o direito brasileiro atribui competência ao Tribunal Marítimo para julgar embarcações mercantes brasileiras em alto-mar, ou em águas estrangeiras e, também, embarcações mercantes estrangeiras em alto-mar, no caso de estarem envolvidas em qualquer

38 CARAVACA, Alfonso-Luis Calvo; GONZÁLEZ, Javier Carrascosa. Derecho internacional privado. 14. ed. Granada: Comares, 2014. v. 1. p. 1.125. O problema continua em se estabelecer as regras de competência em alto-mar, principalmente quando se tratar de navios que arvoram bandeiras de conveniência. acidente marítimo ou incidente de navegação, no qual tenha pessoa física brasileira perdido a vida ou sofrido ferimentos graves, ou que tenham provocado danos graves a navios ou a instalações brasileiras ou ao meio marinho, de acordo com as normas do Direito Internacional. ${ }^{39} \mathrm{O}$ tribunal marítimo tem julgado os casos em alto-mar aplicando as leis brasileiras, como ementados nos casos abaixo:

\section{Ementa: B/M "SANTA MARTA II". Pane de máquinas, deixando a embarcação à deriva em alto-mar. Deficiência de manutenção. Negligência. Condenação. (Tribunal Marítimo, Processo $\mathrm{n}^{\circ}$ 15.684, Data do Julgamento: 18/06/1996). \\ Ementa: Abalroamento em alto-mar. Causa: ma interpretação das Regras do R IPEAM. Condenação. (Tribunal Marítimo, Processo $\mathrm{n}^{\circ}$ 7.758, Data do Julgamento: 03/05/1977). \\ Ementa: Naufrágio de navio estrangeiro em alto mar. Incompetência do Tribunal Marítimo. Tribunal Marítimo, Processo $n^{\circ}$ 944, Data do Julgamento: 17/01/1950).}

A CNUDM estabelece regras sobre jurisdição penal em caso de abalroamento ou de qualquer outro incidente de navegação ocorrido a um navio no alto-mar que possa acarretar uma responsabilidade penal ou disciplinar para o capitão ou para qualquer outra pessoa ao serviço do navio, nas quais os procedimentos penais e disciplinares contras essas pessoas só podem ser iniciados perante as autoridades judiciais ou administrativas a competência do Estado de bandeira ou perante as do Estado do qual essas pessoas sejam nacionais, conforme o artigo 97.

No que tange à imunidade de jurisdição, o artigo define os casos em que os navios ou embarcações de um Estado estarão submetidos exclusivamente à lei do pavilhão/bandeira em mar internacional, conforme dispõe os artigos 95 e 96 da CNUDM. São eles: os navios de guerra no alto-mar, que gozam de completa imunidade de jurisdição relativamente a qualquer outro Estado que não seja o da sua bandeira e os navios utilizados unicamente em serviço oficial não comercial. Os navios pertencentes a um Estado ou por ele operados e utilizados unicamente em serviço oficial não comercial gozam, no alto-mar, de completa imunidade de jurisdição relativamente a qualquer Estado que não seja o da sua bandeira.

39 Lei no 2180/1954, artigo 10. 


\section{OS TRIBUNAIS BRASILEIROS E A COMPETÊNCIA INTERNACIONAL PARA POLUIÇÃO MARINHA DE HIDROCARBONETOS E SEUS DERIVADOS CAUSADOS POR NAVIOS ESTRANGEIROS}

O transporte marítimo é considerado de alto risco quando carrega substâncias nocivas ou perigosas que, se descarregada nas águas, é capaz de gerar riscos ou causar danos à saúde humana, ao ecossistema aquático ou prejudicar o uso da água e de seu entorno. Busca-se, assim, um equilíbrio entre as atividades de navegação e o meio ambiente, com políticas e medidas de proteção ao meio ambiente marinho, assim como a das populações que habitam o entorno e, algumas delas, dependem do mar como fonte de subsistência, como as atividades dos pescadores.

Os principais casos de poluição marinha por petróleo e seus derivados no Brasil foram causados por transportes marítimos, incluindo navios nacionais e estrangeiros. Esses casos foram apreciados pelos tribunais brasileiros que reconhecem a responsabilidade objetiva, independentemente de culpa do agente. Ainda que o dano causado seja de pouca gravidade e a empresa tenha tomado todas as medidas necessárias à contenção e recolhimento do óleo derramado da embarcação, isso não a desqualifica como poluidora-pagadora, aplicando-se o próprio princípio de que aquele que causar danos ao meio ambiente ficará sujeito a sanções penais e administrativas, sem prejuízo da obrigação de promover a reparação dos danos ocasionados. Na Apelação Cível julgada pelo Tribunal Regional Federal (TRF) da $3^{\text {a }}$ Região, o juiz destacou que "mesmo que se considere a sua quantidade e adoção das medidas necessárias à sua imediata contenção e remoção, há de se ponderar que o derramamento de óleo no mar sempre ocasionará um dano ao meio ambiente, pois provocará um desequilíbrio à fauna e à flora locais". ${ }^{40}$

As empresas exploradoras de petróleo e seus derivados também podem ser responsabilizadas por danos ao

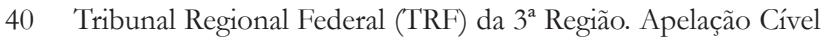
nº10607 SP 0010607-88.2011.4.03.6104, Relator: juiz convocado Roberto Jeuken, data de julgamento: 06/11/2014, Terceira Turma. Ementa: Ação civil pública. Indenização. Dano ambiental. Derramamento de óleo no mar. Responsabilidade objetiva. Indenização devida. Valor monetário da indenização. Proposta emitida conforme critério estabelecido pela CETESB. Peculiaridades do caso concreto. Princípios da razoabilidade e da proporcionalidade. Honorários advocatícios incabíveis. meio ambiente marinho causados por óleo, principalmente em áreas de domínio do Estado, como no caso da zona econômica exclusiva. Veja-se o exemplo da área do pré-sal. Varella ressalta que embora as empresas estejam investindo recursos financeiros muito elevado para a extração do petróleo, há um grande potencial de impacto ambiental. Nesse sentido, o autor afirma que "e ste cenário formidável sublinha a importância de um quadro jurídico correto para evitar desastres graves". ${ }^{41}$

O artigo IX da Convenção Internacional sobre Responsabilidade Civil em Danos Causados por Poluição por Óleo, de 1969, ${ }^{42}$ estabelece a competência internacional dos Estados

1. Quando um incidente tiver causado dano por poluição num território, incluindo o mar territorial de um ou mais estados contratantes, ou quando em tal território, incluindo o mar territorial, foram tomadas medidas preventivas para evitar ou minimizar o dano pela poluição, as ações para Indenização somente poderão ser impetradas nos tribunais desse ou desses estados contratantes. [...]

2. Cada Estado contratante deverá se assegurar de que seus tribunais são competentes para conhecer tais ações de indenização.

Assim, a convenção visa harmonizar os direitos nacionais aos padrões internacionais, aplicando-se a regra do forum damni, independentemente da lei da bandeira ou do pavilhão. A vantagem do reconhecimento da competência internacional do local do dano afasta o forum shopping e tem maior aproximação com o evento danoso. Assim, os tribunais brasileiros são competentes para julgar os danos ocorridos em mar territorial e na zona econômica exclusiva.

Em 1987, o navio de bandeira liberiana, atracado no Porto do São Sebastião casou dano ambiental por derramamento de óleo em razão de defeito na válvula, que provocou o transbordo do tanque. Foi lavrado o auto de infração e aplicação de multa. O Supremo Tribunal Federal (STF) negou seguimento ao recurso extraordinário e manteve a decisão do Tribunal Regional Federal da $3^{\mathrm{a}}$ Região, uma vez que "envolveria a reapreciação do conjunto probatório que permeia a causa, bem assim da legislação infraconstitucional pertinente, o que é inadmissível

41 In Varella, Marcelo D. A necessidade de repensar os mecanismos de responsabilidade ambiental em caso de riscos de vazamento de petróleo em altomar no Brasil. Revista de Direito Internacional, vol.12, no.1. (nesta edição).

42 Aprovada pelo Decreto Legislativo $\mathrm{n}^{\circ} 74$ de 30 de setembro de 1976 e promulgada pelo Decreto n ${ }^{\circ}$ 79.437, de 28 de março de 1977. 
em recurso extraordinário, podendo configurar apenas ofensa indireta ou reflexa à Constituição da República." ${ }^{43}$ Ademais, manteve a multa aplicada no auto de infração pela Capitania dos Portos e determinou como lei aplicável a Lei $n^{\circ}$. 5.357/67, que dispõe sobre as infrações aplicáveis aos navios e terminais, marítimos ou fluviais, que derramarem ou lançarem óleo ou detritos em mar territorial brasileiro. $\mathrm{O}$ acórdão a quo declarou que

\begin{abstract}
quanto ao outro fundamento deduzido, para justificar que a multa imposta é indevida, consistente na alegação de que o óleo derramado no mar foi imediatamente recolhido, não se caracterizando a infração, pois foi evitada a poluição, ou seja, não se consumou o dano ambiental, não merece prosperar, pois, o procedimento de sindicância instaurada para apurar as causas do derramamento do óleo, estimou em 75 metros cúbicos o volume de óleo derramado, ou seja, 75.000 litros, poluindo as águas do Canal de São Sebastião. E, ainda que tenha sido bem-sucedida a operação de recolhimento do óleo, promovida pelos órgãos competentes brasileiros, conforme consta do relatório do CODEL (Comitê de Defesa do Litoral), tal fato não afasta o evidente dano ambiental causado pelo navio, resultando sim em prejuízos irreversíveis ao meio ambiente, considerando inclusive o teor do auto de exame pericial acostado aos autos. ${ }^{44}$
\end{abstract}

Nos contratos de afretamento, a empresa brasileira que contrata navio nacional, ou estrangeiro para transporte de óleo, responde objetiva e solidariamente por todos os danos causados ao meio ambiente marinho. O Superior Tribunal de Justiça (STJ) manteve a decisão afirmando que "a contratação do navio, aí incluída a tripulação, foi feita pela ré. Logo, os responsáveis pela desastrada manobra de atracação, que resultou no vazamento do óleo, eram agentes da ré, pessoa jurídica prestadora de serviço público que detém o monopólio da exploração, transporte e refino do óleo bruto". Além disso, "se a empresa, ré, escolheu mal seus agentes, agiu com negligência e deve responder pelos prejuízos que esses contratados, na qualidade de prepostos, causaram ao exercer o trabalho de sua responsabilidade (fl. 709)." ${ }^{45}$

43 BRASIL. Supremo Tribunal Federal. Recurso Extraordinário, RE $n^{\circ}$ 630236/SP. Relator Ministro Dias Toffoli. Brasília, 08 de novembro de 2013.

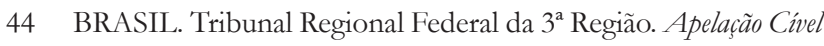
$n^{\circ} 56072$ SP 96.03.056072-3. Turma suplementar da Segunda Seção Direito Administrativo. Relator: juiz convocado Valdeci dos Santos. Brasília, 27 de março 2008. Ementa: Derramamento de óleo. Canal de São Sebastião. Navio de bandeira liberiana. Dano ambiental. Leis n. 5.357/67 E 6.831/81. Auto de infração. Multa. Validade.

45 BRASIL. Superior Tribunal de Justiça. Agravo Recurso Especial $n^{\circ}$ 259.879-SP. Relator: Min. Luis Felipe Salomão. Brasília, 21 de novembro de 2013.
Em outro caso de poluição marinha, um navio de bandeira estrangeira, fretado por empresa brasileira, lançou ao mar de cerca de 500 (quinhentos) litros de petróleo provenientes da operação de descarregamento, em 1993. A Comissão Estadual de Controle Ambiental do Estado do Rio de Janeiro lavrou auto de infração contra a empresa brasileira, Petrobras, pelo dano ao meio ambiente. Em razão disso, a empresa petrolífera ingressou com ação judicial contra o Estado do Rio de Janeiro objetivando anular a multa imposta alegando tanto a incompetência do órgão estadual para aplicação da penalidade quanto à ausência de caracterização objetiva do ato ilícito por ser parte ilegítima para figurar no polo passivo da obrigação. Em sua defesa, a empresa sustentou, ainda, que somente o proprietário da embarcação estrangeira poderia responder pelo dano ambiental, uma vez que a empresa brasileira não possuía qualquer ingerência na direção do navio, afastando-se assim, o dever in elegendo ou in vigilando sobre a tripulação. $\mathrm{O}$ STJ negou provimento ao recurso especial, mantendo sentença monocrática que decidiu que "a pessoa física ou jurídica, de direito público ou privado, responsável direta ou indiretamente e, por atividade de degradação ambiental (art. $3^{\circ}$, inciso IV, da Lei no 6.938/81)". No caso, a empresa brasileira é responsável em razão do risco de sua atividade em causar danos ambientais, que consubstancia o nexo causal de sua responsabilidade, independentemente, de o derramamento de óleo ter ocorrido por culpa da embarcação contratada. ${ }^{46} \mathrm{O}$ ministro relator destacou, ainda, que

[...] merecem tratamento diverso os danos ambientais provocados por embarcação de bandeira estrangeira contratada por empresa nacional cuja atividade, ainda que de forma indireta, seja a causadora do derramamento de óleo, daqueles danos perpetrados por navio estrangeiro a serviço de empresa estrangeira, quando então resta irretorquível a aplicação do art. $2^{\circ}$, do Decreto $n^{\circ} 83.540 / 79$.

Ademais, a empresa tem o direito de ação de regresso contra o culpado mesmo na responsabilidade objetiva em face de suportar o ônus da indenização. O STJ decidiu que a eventual exoneração da recorrente por culpa de terceiro poderá ser aferida em ação regressiva, inter partes. Assim, o poluidor (responsável direto ou indireto) por poluição marinha tem a obrigação de indenizar e/ou reparar os danos causados tanto ao meio ambiente

46 BRASIL. Superior Tribunal de Justiça. Recurso Especial $n^{\circ}$ 467.212-RJ (2002/0106671-6). Relator: Min. Luiz Fux. Brasília, 28 de outubro de 2003. 
quanto a terceiros afetados, independentemente da existência de culpa, sem obstar a aplicação das penalidades administrativas impostas.

Em outro caso, um navio, de bandeira alemã, deu causa a vazamento de óleo no mar, em 2 de maio de 1990, como consequência de manobra errônea para o tanque lastre n. 1, no estuário de Santos, na região do canal de Piaçaguera, no Porto de Santos/SP. O STJ manteve a sentença de primeira instância que fundamentou a fixação do valor indenizatório em parecer emitido pela CETESB, que concluiu que

O derramamento de óleo causou dano ecológico, ao relatar os efeitos que o produto causa aos ecossistemas marinhos por ele infestados, a saber morte direta por reconhecimento e asfixia, morte direta por intoxicação, redução da taxa de fertilização, incorporação de substâncias carcinogênicas, efeitos dito subletais (morte ecológica) e outros ${ }^{47}$

Além disso, o STJ declarou que tanto os artigos $3^{\circ}$ e $4^{\circ}$ da $6.938 / 81$ quanto o artigo $1^{\circ} \mathrm{da}$ Convenção Internacional sobre Responsabilidade Civil em Danos Causados por Poluição de Óleo (CLC-69) se prestariam para alterar o conteúdo do julgamento, pois "consignam a qualificação de poluidor e a consequente necessidade de recuperar a área ambiental e a imposição do dever de indenizar pelos danos causados, como ocorreu na espécie”. Manteve, ainda, a decisão quanto ao início a contagem dos juros de mora, que incide a partir da ocorrência do evento poluidor.

Outro acidente que causou poluição ao meio ambiente marinho e prejuízos à população foi o naufrágio do comboio oceânico, composto por duas embarcações na Baía da Babitonga, na região de São Francisco do Sul/SC, com o vazamento de óleo 107 m3. Segundo o desembargador, o laudo técnico produzido pela Universidade da Região de Joinville (UNIVILLE), na Medida Cautelar de Produção Antecipada de Provas realizada para instruir a Ação Civil Pública,

[...] atestou, de forma inequívoca, que o vazamento de óleo causou a morte de várias espécies de animais marinhos da região, afetando, inclusive, a reprodução destes, uma vez que ovos e larvas de peixes sofreram com o impacto ambiental, criandose a expectativa de que efeitos do incidente deveriam perdurar por aproximadamente três anos. ${ }^{48}$

47 BRASIL. Superior Tribunal de Justiça. Recurso Especial $n^{\circ}$ 735.534-SP. Relator: Min. Castro Meira. Brasília: 20 de novembro de 2008.

48 BRASIL. Superior Tribunal de Justiça. Agravo em Recurso Especial no 530.673-SC. Relator: Min. Buzzi. Brasília, 8 de agosto de 2014.
Além disso, o STJ negou provimento ao agravo em recurso especial, já que na CLC-1969 resta claro que a sua aplicação diz respeito à poluição por óleo decorrente do transporte marítimo de óleo a granel, não alcançando a poluição por óleo decorrente de incidentes com navios cuja carga seja diversa da prevista na Convenção, como é o caso dos autos, que trata de transporte interno, via marítima, de bobinas de aço. ${ }^{49}$. Assim, ficou demonstrado que o acidente causou grande derramamento de óleo e afetou a vida da população, incluindo a dos pescadores, que exerciam suas atividades laborais na região. O STJ manteve a decisão dos tribunais inferiores, mantendo a indenização por danos materiais e morais aos pescadores. ${ }^{50}$

Em todos os casos analisados, verificou-se que não se discutiu a questão da nacionalidade dos navios estrangeiros, mas apenas a questão de fundo que foi a poluição marinha e a responsabilização pelos prejuízos causados ao meio ambiente e à população.

\subsection{O problema do conflito de competência entre justiça federal e justiça estadual}

O comércio internacional por vias marítimas tem impactos ambientais nas atividades portuárias (implantação dos portos e operações portuárias) e nas atividades de navegação propriamente dita, no percurso de um porto a outro. Isso quer dizer que ele pode ocorrer tanto em águas territoriais quanto em águas internacionais. Quando ocorre um acidente supostamente causado por transporte marítimo, independentemente da nacionalidade, em território nacional, surge o conflito de competência para propor a ação civil pública: é competente o juiz da justiça estadual (o do local do dano conforme o artigo $2^{\circ}$ da Lei $n^{\circ} 7357 / 85$ ) ou da justiça federal (conforme dispõe o artigo 109, I, da CF)?

A posição do STJ reconhece a competência da justiça federal quando demonstrado o interesse da União, ou quando se trata de bens lesados de propriedade da União, descritos no artigo 20 da Constituição Federal (CF). Por sua vez, o artigo 109, III, da CF, determina

49 BRASIL. Tribunal Regional Federal da $4^{a}$ Região. Agravo de Instrumento $n^{\circ}$ 90505220104040000 SC 0009050-52.2010.404.0000. Quarta Turma. Relator: Marga Inge Barth Tessler. Brasília, 02 de junho de 2010. Data de Publicação: D.E. 14/06/2010.

50 BRASIL. Superior Tribunal de Justiça. Agravo Em Recurso Especial $n^{\circ}$ 530.673-SC. Relator: Min. Marco Buzzi. Brasília, 8 de agosto de 2014 . 
que compete aos juízes federais processar e julgar as causas fundadas em tratado ou contrato da União com Estado estrangeiro ou organismo internacional.

O objetivo da inserção do inciso III no artigo 109 foi atribuir à justiça federal as causas que envolvem tratados internacionais que criam obrigações para o Estado brasileiro de interesses públicos subjetivos, chamados tratados-contratos e não os tratados normativos de caráter geral. Embora o tratado seja classificado quanto à matéria em tratado-contrato e tratado-lei, a doutrina afasta esse entendimento de que o tratado internacional pode ser acordado para diversos propósitos como contratos, normas, acordos políticos, assim como estabelecer regras para entrada e saída de meios de transporte marítimos por exemplo. Nesse contexto, Waldock afirma que "the relevant distinction, it is increasingly recognised, is between particular law-making and general law-making treaties rather than between treaty-contacts and treaty-laws" ${ }^{\prime \prime}$.

Desse modo, a justiça federal deve ser competente para os tratados que criam normas ou estabeleçam obrigações particulares para atender aos interesses das partes envolvidas, ou seja, naquelas em que o Estado brasileiro (União) tenha interesse particular sobre a questão e não para os tratados internacionais de maneira geral. Nesse sentido, quando se tratar de poluição marinha de hidrocarbonetos e seus derivados objetivando a condenação do poluidor-pagador, haverá interesse da União na proteção de um bem público. No caso de acidentes marítimos em comarca onde não há justiça federal, o STJ decidiu o conflito de competência:

CONFLITO DE COMPETENCIA. AC̄̃̃O CIVIL PÚBLICA. DANO AMBIENTAL. VAZAMENTO DE GASOLINA NO ESTUARIO DE SANTOS. COMARCA SEDE DE VARA FEDERAL. INTERESSE DA UNIÃO. CONTROVERSIA REGIDA POR CONVENÇÃO INTERNACIONAL. COMPETENCIA DOS JUIZES FEDERAIS. A ação civil pública, proposta com base na lei n. 7347, de 24 de julho de 1985, deve ser ajuizada no foro do local onde ocorreu o dano (art. $2^{\circ}$.). Tratando-se de comarca em que não ha juiz federal, será competente o juiz de direito do estado, em primeiro grau, para processar e julgar a ação, conforme a regra excepcional do artigo 109, $\int 3^{\circ}$, da Carta Magna. Sendo o local sede de Vara Federal, aos juízes federais compete o processo e julgamento, não só pelo interesse da união na causa,

51 WALDOCK, Humphrey. General course on public international law. p. 76 como porque assim se procede em todas as causas fundadas em tratado ou contrato da União com Estado estrangeiro ou organismo internacional (art. 109, I e III, CF). ${ }^{52}$

Enquanto a competência legislativa seja concorrente entre União, Estados e | Municípios, cabendo ao último a competência residual, a competência judiciária também é concorrente entre a justiça federal e estadual para os litígios transfronteriços, gerando problemas na atuação prática para soluções rápidas aos danos ambientais, principalmente de substâncias classificadas altamente poluidoras. Ações conjuntas entre os órgãos do Poder Judiciário são essenciais para a proteção efetiva do meio ambiente da responsabilização dos causadores dos danos, independentemente da nacionalidade das embarcações.

\subsection{O problema do conflito de competência entre órgãos administrativos federais e estaduais}

Além dos problemas relacionados à competência judiciária concorrente em conflitos transnacionais, há também conflitos de competência no exercício do poder de polícia dos órgãos administrativos. No que tange à aplicação de multas por danos causados ao meio ambiente marinho, os órgãos federais e estudais têm competência fiscalizatória, conferindo-lhes a atribuição de aplicar penalidades definidas. Segundo o entendimento da jurisprudência brasileira, a competência da Capitania dos Portos (União) não é exclusiva, mas complementar a dos órgãos estaduais, conforme a ementa abaixo:

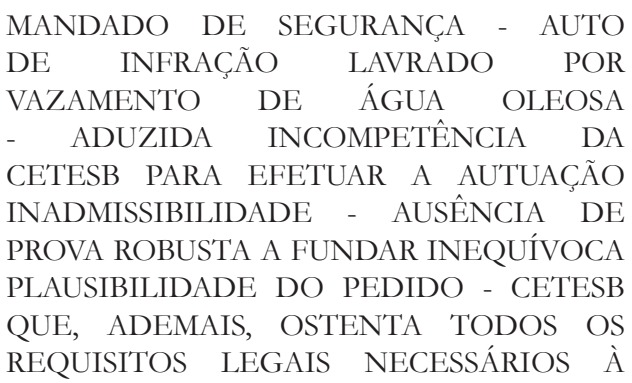

52 BRASIL. Superior Tribunal de Justiça. Conflito de Competência $n^{\circ}$ 3389 SP 1992/0019685-3. Relator: Min. Hélio Mosimann. Brasília, 25 de maio de 1993, S1 - Primeira Seção. Data de Publicação: DJ 21.06.1993 p. 12330 RSTJ vol. 50 p. 30); BRASIL. Superior Tribunal de Justiça. Conflito de Competência n ${ }^{\circ} 3389$ / SP. Relator: Min. Hélio Mosimann. Brasília, 25 de maio de 1993; BRASIL. Superior tribunal de Justiça. Embargos de Declaração no Conflito de Competência no 2473- SP. Relator: Min. Antônio De Pádua Ribeiro. Brasília, 20 de abril de 1993. Veja também os conflitos de competência no STJ, $\mathrm{n}^{\circ}$ 2.473/ SP e no $16.863 /$ SP. 
AUTUAÇÃODEQUEM PRATICA ATIVIDADE LESIVA AO MEIO AMBIENTE NO ESTADO DE SÃO PAULO - APELO DESPROVIDO..$^{53}$

Desse modo, o entendimento com relação à multa é de se evitar a ocorrência do bis in idem, e que o poluidor-pagador pague duas vezes.

Por sua vez, nos casos de interesses de particulares afetados pela poluição marinha, as ações de indenização por pessoas lesadas em acidentes causados por transporte marítimo por poluição por óleo, a competência é da justiça estadual. Contudo, em alguns casos, se questiona se haveria interesse jurídico da União no feito, ou de órgão federal como o IBAMA, por exemplo, o que afastaria a competência estadual ou quando chamada ao processo deve se manifestar, conforme a decisão a seguir:

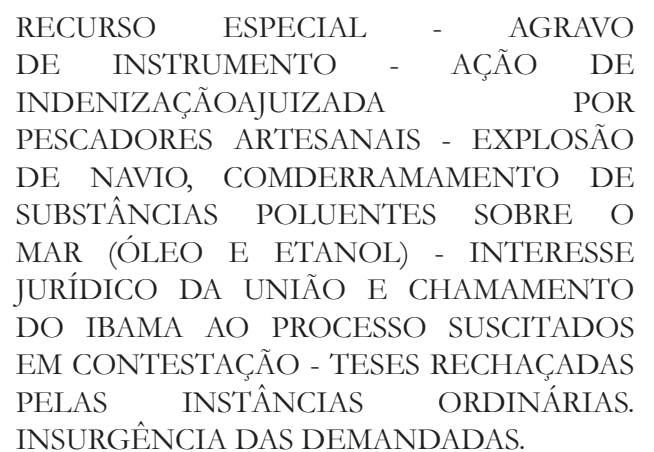

1. Não se conhece da tese de afronta ao art. 535 do CPC quando aparte recorrente não indica precisamente, nas razões articuladas no recurso especial, as omissões em que supostamente incorreu o acórdão recorrido. Incidência da Súmula n. 284/ STF. 2. Competência da Justiça Federal. Suposta incidência de convenção internacional (art. 109, III, da CF/88). Inocorrência. Demanda cuja causa de pedir não veicula tema afeto ao aludido órgão do Poder Judiciário. No caso dos autos, além de a ação indenizatória não se encontrar lastrada em qualquer convenção internacional, com ela não se objetiva a reparação de danos ambientais (causados a bens da União), mas sim o ressarcimento dos prejuízos suportados, em tese, por particulares (pescadores), em face da impossibilidade de desenvolverem a pesca na região atingida pelo desastre ambiental. 3. A alegação de existência de interesse jurídico da União, formulada por uma das partes em ação indenizatória, mas sem subsumir-se a qualquer das formas de intervenção de terceiro provocada (chamamento ao processo, denunciação à lide ou nomeação à autoria - arts. 62, 70 e 77 do CPC), não enseja o automático deslocamento do feito para a Justiça Federal. 4. À luz do Enunciado n.

53 SÃO PAULO. Tribunal de Justiça do Estado de São Paulo. Apelação $n^{\circ}$ 0247845-35.2009.8.26.0000. Relator: Renato Nalini. São Paulo, 16 de junho de 2011, Câmara Reservada ao Meio Ambiente.
150 da Súmula do STJ, compete à Justiça Federal decidir sobre a existência de interesse jurídico espontaneamente revelado pela União. Hipótese concreta em que o órgão estatal não manifestou qualquer interesse voluntário em intervir na lide. 5 . Eventual existência de demanda regressiva proposta pela União contra os responsáveis pelo dano ambiental, em razão do pagamento de benefício extraordinário aos pescadores (a título de segurodesemprego), não traduz manifestação espontânea do ente político na presente contenda reparatória de danos morais em materiais. 6. Em havendo pedido expresso de chamamento do IBAMA (autarquia federal) ao processo, é de rigor a remessa dos autos à Justiça Federal, a fim de aquilatar a presença de interesse da União que justifique o processamento da ação perante o aludido órgão do Poder Judiciário. 7. Recurso especial conhecido em parte, e, nesta extensão, parcialmente provido. ${ }^{54}$

A dicotomia entre interesses públicos e privados e ente justiça federal e estadual e entre os órgãos administrativos tem gerado problemas práticos para os profissionais na defesa dos interesses daqueles que sofrem prejuízos causados por poluição marinha.

Por fim, nota-se que esses casos de conflitos de competência entre as autoridades judiciárias, federal e estadual, assim como a competência dos órgãos administrativos no exercício do poder de polícia, como órgãos fiscalizatórios, em casos danos ao meio ambiente marinho devem ter em conta a reparação do dano ou da pessoa lesada. Esse é o objetivo principal da responsabilidade civil extracontratual, que, nos casos de poluição marinha, de baixo ou alto grau, a responsabilidade é objetiva, solidária e independe de culpa. Assim, a prestação judiciária deve ser efetiva de modo a responsabilizar o poluidor, que além de recuperar a área degradada, tem o dever de indenizar as pessoas lesadas.

\section{Considerações finais}

A responsabilidade civil extracontratual por danos ambientais marinhos causados por transportes marítimos está consagrada no direito brasileiro tanto no campo normativo quanto na responsabilização do poluidor-pagador pelos tribunais administrativos e judiciais. Contudo, as regras de direito internacional privado relacionados especificamente à responsabilidade civil

54 BRASIL. Superior Tribunal de Justiça. Recurso Especial $n^{\circ}$ 1.187.097-PR 2010/0056034-0. Quarta Turma. Relator: Min. Marco Buzzi. Brasília, 16 de abril de 2013. 
extracontratual não estão consagradas expressamente no direito brasileiro, nem no âmbito do Mercosul. Em sentido diametralmente oposto, houve um grande avanço no sobre o assunto na União Europeia a partir da criação do Regulamento (CE) no 864/2007 relativo à lei aplicável às obrigações extracontratuais, conhecido como "Roma II". Essa norma de direito internacional privado comunitário além de prever normas gerais de direito aplicável, adota regras específicas para diversas matérias incluindo a de danos ambientais. A certeza da lei aplicável a litígios transnacionais torna o resultado mais previsível e facilita a cooperação jurídica internacional, oferece maior segurança jurídica para o reconhecimento e execução de sentenças estrangeiras.

De acordo com a análise jurisprudencial dos tribunais brasileiros, a lei aplicável é a lei local onde o dano ocorreu, lex damni. Assim, aplica-se a lei nacional aos casos de poluição marinha ocorridos em águas brasileiras (mar territorial, zona econômica exclusiva e as águas sobrejacentes à plataforma continental) causados por transportes marítimo, nacionais ou estrangeiras, independentemente da lei da bandeira do navio. A lex damni é a regra de maior aproximação do fato para não penas punir o poluidor mas principalmente para reparar o dano. Nesse sentido, as embarcações estrangeiras estão sujeitas às leis brasileiras quando em águas domésticas.

A Organização Marítima Internacional (OMI) constitui a principal instituição no seio do sistema das Nações que exerce um papel importante nas políticas públicas globais para o direito marítimo. Busca-se estabelecer um equilíbrio entre as atividades econômicas da indústria da navegação e o meio ambiente marinho, reconhecido como um bem público global. A OMI é responsável pela construção de um arcabouço jurídico e pela unificação do direito marítimo, com a adoção de inúmeras convenções internacionais, para promover a segurança na navegação, evitando colisões de navios no mar, e, também, prevenir a poluição marinha, principalmente por substâncias altamente perigosas e nocivas ao meio ambiente marinho. Entretanto, não há regras claras sobre a lei aplicável aos casos de poluição marinha que ocorrem em alto-mar.

Além disso, as fontes para a responsabilização extracontratual por danos ao meio ambiente marinho, causados por transportes marítimos são tanto as normas internas quanto as normas internacionais, quando os tratados internacionais tiverem sido ratificados e ou ade- ridos e incorporadas ao ordenamento jurídico interno.

No caso de colisão ou abalroamento, aplica-se a regra da lex fori. Desse modo, aplica-se a lei local do acidente. Em alto-mar a regra geral é a lei da bandeira ou do pavilhão do causador do dano. Porém, as regras estabelecidas na Convenção das Nações Unidas sobre Direito do Mar não garantem direitos daqueles que utilizam as bandeiras de conveniência.

Contudo, apesar da harmonização entre as normas internas e internacionais, observa-se uma verdadeira fragmentação na aplicação das fontes ao caso concreto em relação às competências dos tribunais brasileiros.

São competentes as autoridades administrativas e judiciais quando o ato ou fato ocorrerem em águas sob a jurisdição nacional. Contudo, considerando os efeitos dos danos plurilocalizados, a jurisdição não é absoluta, mas concorrente. Desse modo, em caso de colisão em águas estrangeiras ou internacionais, o Tribunal Marítimo tem competência para examinar e punir administrativamente os atos ilícitos praticados pela tripulação do navio, por imprudência ou negligência.

Ademais, as autoridades administrativas locais, federais e estaduais também são competentes como órgãos fiscalizadores, com poderes para a aplicação de medidas administrativas, como a lavratura do auto de infração e a consequente aplicação de multa. A aplicação de sanções administrativas a navios independe de sua nacionalidade.

As empresas brasileiras se vinculam a navios ou a embarcações estrangeiras por contratos de afretamento, e respondem objetiva e solidariamente aos danos. Além disso, as empresas de navegação têm questionado perante o Poder Judiciário a validade dessas multas em razão da competência ser da justiça federal ou estadual. A posição dos tribunais brasileiros ocorre no sentido de validar o ato administrativo, mas afastar o bis in idem.

Com relação à competência para julgar os litígios por danos ao meio ambiente marinho, o direito brasileiro atribui competência tanto à justiça estadual quanto à federal. Aplica-se a regra do forum damni. Há um verdadeiro conflito de competência em direito interno que leva a inúmeros questionamentos na justiça brasileira para se determinar a competência, onerando aqueles que sofreram diretamente o dano. Isso afeta a efetividade da prestação jurisdicional e o princípio da economia processual. 
Notam-se nos julgados referentes aos conflitos de competência interna entre justiça estadual e federal é um campo normativo bastante intenso, pois as regras de competência são definidas pelos tribunais levando-se em consideração três elementos: a pessoa que sofreu o dano, o ato ou fato lícito ou ilícito e a lei aplicável ao caso concreto.

Nos casos de responsabilidade extracontratual por danos ambientais causados por transportes marítimos, a competência para julgar os prejuízos sofridos pelas pessoas é da justiça estadual, independentemente da lei aplicável ao caso concreto. É o caso de pescadores que tiveram suas atividades interrompidas por causa da poluição marinha, estes têm direito à reparação por danos materiais (indenização por lucros cessantes) e danos morais (em razão do sofrimento dos pescados pela privação das condições de trabalho), a contar data em que o dano ocorreu. As embarcações estrangeiras são responsáveis pelos danos causados e as empresas vinculadas pelos contratos de afretamento respondem objetiva e solidariamente, devendo reparar os prejuízos sofridos pelas pessoas vítimas do acidente. A nacionalidade do navio é uma questão secundária, cabendo, todavia, ação de regresso da empresa condenada ao poluidor de fato.

Nos casos de responsabilidade extracontratual por danos ambientais causados por transportes marítimos, a competência para julgar o ato lícito ou ilícito é concorrente, isto é, atribui-se competência tanto a justiça estadual quanto a federal. As competências se diferenciam pela lei aplicável ao caso concreto. De acordo com o entendimento jurisprudencial do Superior Tribunal de Justiça, a competência será da justiça federal para processar e julgar a ação civil pública com a finalidade de reparar os danos ao meio ambiente marinho causados por vazamento ou derramamento de hidrocarbonetos em duas situações: (i) quando houver interesse da União, por constituírem bens de sua propriedade os terrenos de marinha e o mar territorial; e (ii) quando a causa estiver fundada em Convenção Internacional sobre Responsabilidade Civil em Danos Causados por Poluição por Óleo.

Em relação à competência internacional, o Superior Tribunal de Justiça reconhece a aplicação do forum damni. Assim, o tribunal estrangeiro é competente para processar e jugar os casos de responsabilidade extracontratual por poluição marinha, incluindo os navios de bandeira brasileira, causadores do dano. Além disso, os Estados devem assegurar a responsabilidade civil extracontratual transfronteiriça por poluição marinha causada por pessoas privadas, seja pelo reconhecimento e execução de decisões estrangeiras, seja pelo cumprimento das diligências solicitadas por cartas rogatórias ou auxílio direto. Utilizar-se-á, os mecanismos da cooperação jurídica internacional para assegurar ao Estado em que ocorreu o dano, a reparação do meio ambiente lesado, com a restitutio in intergrum, sempre que possível, assim como a indenização às vítimas. Em caso de dúvida, devem-se aplicar os princípios in dubio pro societas e in dubio pro natura.

\section{REFERÊNCIAS}

ANTUNES, Paulo de Bessa. Dano ambiental: uma abordagem conceitual. Rio de Janeiro: Lumen Juris, 2000.

BERNASCONI, Christophe. Civil liability resulting from transfrontier environmental damage: a case for the Hague Conference? Disponível em: <http://www.hcch.net/ upload/wop/gen_pd8e.pdf>. Acesso em: 14 ago. 2014.

BOYLE, A. E. Globalising Environmental Liability: the interplay of national and international law. Journal of Environmental Law, v. 17, n. 1, p. 3-26, 2005.

CARAVACA, Alfonso-Luis Calvo; GONZÁLEZ, Javier Carrascosa. Derecho internacional privado. 14. ed. Granada: Comares, 2014. v. 1.

CARBONE, Sergio M. Conflits de lois en droit maritime. The Hague Academy of International Law, 2009.

CASTRO JUNIOR, Osvaldo Agripino de. Principais aspectos do direito marítimo e sua relação com a Lex Mercatoria e Lex Maritima. Revista Sequência Estudos Jurídicos e Políticos, v. 31, n. 61, p. 195-225, dez. 2010,

CHENG, Chia-Jui (Ed.). Clive M Schmitthoff's Select Essays on International Trade Law. Dordrecht: Martinus Nijhoff Publishers; Boston, London: Graham \& Trotman, 1982.

CHESHIRE, Peter North; FAWCETT, James; CARRUTHERS, Janeen. Cheshire, North \& Fawcett. Private International Law. Oxford: OUP, 2008.

COMPANHIA AMBIENTAL DO ESTADO DE SÃO PAULO. Tabela 1. Ocorrências envolvendo petróleo e derivados no Brasil (1960-2012). Disponível em: <http:/ / www.cetesb.sp.gov.br/userfiles/file/emergencias-qui- 
micas/panorama-geral/Principais-Acidentes-Brasiltab1.pdf>. Acesso em: 10 mar. 2014.

CONFERÊNCIA DAS NAÇÕES UNIDAS SOBRE COMÉRCIO E DESENVOLVIMENTO. Review of maritime transport. Geneva: United Nations Publication, 2014.

IANNI, Otavio. Teoria da globalização. Rio de Janeiro: Civilização Brasileira, 1997.

IBARS, Ingrid Sisteré. Corporate Social Responsibility in the Shipping Business. Master Thesis. Supervisor: Proshanto K. Mukherjee. Faculty of law Lund University. Sweden: Spring, 2013.

ILA. Report. International Law Association Berlin Conference (2004) Transnational Enforcement Of Environmental Law, 2004.

MARTINS, Eliane M. Octaviano. Desenvolvimento sustentável e transportes marítimos. Revista Direitos Fundamentais \& Democracia, v. 1, 2007.

MARTINS, Eliane M. Octaviano. Segurança Marítima vis-à-vis Desenvolvimento Sustentável. Revista CEJ, Brasília, ano 11, n. 37, p. 103-107, abr./jun. 2007.

ORGANIZAÇÃO MARÍTIMA INTERNACIONAL. Focus on IMO. Imo and dangerous goods at sea. May 1996, Disponível em: < http://www.imo.org/blast/blastDataHelper.asp?data_id $=7999 \&$ filename $=$ IMDGdangero usgoodsfocus1997.pdf>. Acesso em: 12 jul. 2014.

ORGANIZAÇÃO MARÍTIMA INTERNACIONAL. International Shipping Facts and Figures. Maritime Knowleg- de Centre, 2012.

PINHEIRO, Luís de Lima. Temas de direito maritimo: o navio em direito internacional. Disponível em: <http://www.oa.pt/upl/\%7Ba7992dcf-4940-4738acd7-c9fc7e4e58c1\%7D.pdf>. Acesso em: 12 fev. 2014. POCUCA, Milojka; ZANNE Marina. Globalization, International Trade and Maritime Transport. Disponível em: $<$ http:/ / www.google.com.br/url?sa $=$ t\&rct=j\&q=\&esr $\mathrm{c}=\mathrm{s} \&$ source $=$ web\&cd $=1 \& v e d=0 \mathrm{CCkQFjAA \& url}=\mathrm{htt}$ $\mathrm{p} \% 3 \mathrm{~A} \% 2 \mathrm{~F} \% 2 \mathrm{Fwww.fpp} . u n i-1 j . s i \% 2 \mathrm{Fmma}$ bin.php $\% 3$ Fid\%3D2010101801382606\&ei $=$ cd5CVe3EOuTbsAS IlYC4Cw\&usg=AFQjCNE5Mo84x6uOhgE_TQRHgmQBkgnxA\&sig2=6EtfrO-byPWfFjysUpHpqA\&bvm =bv.92189499,d.cWc >. Acesso em: 9 mar. 2015.

SCOVAZZI., Tullio. Chapter 13 Maritime Accidents with Particular Emphasis on Liability and Compensation for Damage from the Exploitation of Mineral Resources of the Seabed, p. 287-320. In: GUTTRY, Andrea; GESTRI, Marco; VENTURINI, Gabriella (Ed.). International disaster response law. Hague: T.M.C. Asser Press, 2012.

SOARES, Guido Fernandes Silva. Direito internacional do meio ambiente: emergência, obrigações e responsabilidades. São Paulo: Atlas, 2001.

Varella, Marcelo D. A necessidade de repensar os mecanismos de responsabilidade ambiental em caso de riscos de vazamento de petróleo em alto-mar no Brasil. Revista de Direito Internacional, vol.12, no.1. (nesta edição).

WALDOCK, Humphrey. General course on public international law. 
Para publicar na Revista de Direito Internacional, acesse o endereço eletrônico www.rdi.uniceub.br ou www.brazilianjournal.org.

Observe as normas de publicação, para facilitar e agilizar o trabalho de edição. 